\title{
Monocytes and Macrophages as Viral Targets and Reservoirs
}

\author{
Ekaterina Nikitina ${ }^{1,2,3, *}$, Irina Larionova ${ }^{3,4}$, Evgeniy Choinzonov ${ }^{5}$ and Julia Kzhyshkowska ${ }^{3,6}$ \\ 1 Department of Episomal-Persistent DNA in Cancer- and Chronic Diseases, German Cancer Research Center, \\ 69120 Heidelberg, Germany \\ 2 Department of Oncovirology, Cancer Research Institute, Tomsk National Research Medical Center, \\ Russian Academy of Sciences, Tomsk 634050, Russia \\ 3 Department of Translational Cellular and Molecular Biomedicine, Tomsk State University, Tomsk 634050, \\ Russia; mitrof_@mail.ru (I.L.); Julia.kzhyshkowska@medma.uni-heidelberg.de (J.K.) \\ 4 Department of Molecular Oncology and Immunology, Cancer Research Institute, Tomsk National Research \\ Medical Center, Russian Academy of Sciences, Tomsk 634050, Russia \\ 5 Head and Neck Department, Cancer Research Institute, Tomsk National Research Medical Center, \\ Russian Academy of Sciences, Tomsk 634050, Russia; choynzonov@tnimc.ru \\ 6 Institute of Transfusion Medicine and Immunology, Medical Faculty Mannheim, Heidelberg University, \\ 68167 Heidelberg, Germany \\ * Correspondence: e.nikitina@dkfz.de or ekatarinanikitina@gmail.com; Tel.: +49-(0)622142-4825
}

Received: 26 June 2018; Accepted: 14 September 2018; Published: 18 September 2018

\begin{abstract}
Viruses manipulate cell biology to utilize monocytes/macrophages as vessels for dissemination, long-term persistence within tissues and virus replication. Viruses enter cells through endocytosis, phagocytosis, macropinocytosis or membrane fusion. These processes play important roles in the mechanisms contributing to the pathogenesis of these agents and in establishing viral genome persistence and latency. Upon viral infection, monocytes respond with an elevated expression of proinflammatory signalling molecules and antiviral responses, as is shown in the case of the influenza, Chikungunya, human herpes and Zika viruses. Human immunodeficiency virus initiates acute inflammation on site during the early stages of infection but there is a shift of M1 to M2 at the later stages of infection. Cytomegalovirus creates a balance between pro- and anti-inflammatory processes by inducing a specific phenotype within the M1/M2 continuum. Despite facilitating inflammation, infected macrophages generally display abolished apoptosis and restricted cytopathic effect, which sustains the virus production. The majority of viruses discussed in this review employ monocytes/macrophages as a repository but certain viruses use these cells for productive replication. This review focuses on viral adaptations to enter monocytes/macrophages, immune escape, reprogramming of infected cells and the response of the host cells.
\end{abstract}

Keywords: monocyte/macrophage; virus; persistence; reservoir; cell response; inflammation; cancer

\section{Introduction}

Infectious agents must find, attack and enter permissive cells, avoid the immune response and productively replicate their genomes. Additionally, these agents must consolidate, that is, establish a persistent infection in an organism with the aim of viral army replenishment and a continuation of its lifecycle. To be a viral reservoir, cells must meet the following characteristics: have a sufficient lifespan, be able to avoid apoptosis and the immune response and have facile interactions with other cell populations. Some cells have these characteristics inherently but others can be transformed and adapted by viral infection, resulting in similar effects. These findings are validated by several results described in this review. Monocytes (Mo) by definition are non-dividing 
cells with a short half-life that makes viral replication difficult or almost impossible. A limited lifespan, limited cell resources, programmed cell death and an immune response are major restrictive characteristics of monocytes/macrophages as a permissive system and/or a reservoir. Nevertheless, monocytes/macrophages have several appealing characteristics as a target for viral infection, thus viruses have found ways to avoid the limitations and adapt these cells for their replication. Monocytes are broadly represented in the blood stream; they continuously differentiate from bone marrow precursors and enter into the circulation where they can be exposed to viral particles. Monocytes are at the front line in the defence against foreign invasion by microorganisms, providing the first virus-cell contact upon infection. Monocytes are professional antigen-presenting cells with a broad repertoire of receptors on the cell surface and high phagocytic activity, which can be exploited by viruses. As a host defender, upon infection, monocytes change their cytokine/chemokine pattern, which directs cell differentiation into long-lived macrophages $(\mathrm{M} \phi)$ and promotes migration into tissue where they become infected resident cells. This gives viruses the possibility to disseminate through all organs and tissues, including the brain (also known as the "Trojan horse" hypothesis [1,2]), forming stable and long-lived reservoirs which can be used for virus replenishment upon favourable conditions for reactivation. Additionally, $\mathrm{Mo} / \mathrm{M} \phi$ are involved in the vertical transmission of virus from an infected mother to the developing foetus in utero [3]. Mo/M $\phi$ can actively interact with other cell populations through direct cell-to-cell contacts, providing a basis for virus dissemination. Finally, monocytes/macrophages are powerful producers of cytokines/chemokines that are involved in the immune response and inflammation initiation and this can be modulated and utilized by viruses for infection spread and establishment. In the current review, these aspects are discussed in detail and are presented with representative examples.

Many types of viruses have been subject to comprehensive investigations exploring monocyte/macrophages-virus interactions, the molecular basis of these interactions, response and permissiveness. For some viral families such as Retroviridae (e.g., human immunodeficiency virus or HIV) and Herpesviridae (e.g., cytomegalovirus or CMV), information has been obtained and presented in detail due to their great importance to public health. This is highlighted by their worldwide role in millions of deaths each year. However, several questions remain unanswered due to the versatile biology of viruses, their resourcefulness and the diversity of monocyte/macrophage polarization and tissue specificity.

This review analyses previously published data on the myeloid cell lineage, with a primary focus on the interaction between monocytes/macrophages and viruses. This paper intends to highlight the aspects of cell regulation that viruses adopt to enable viral persistence, beginning with viral entry and then examining the launching of vital pathways and the regulation of many processes. Intriguing data presented in the literature has shown that, despite their small sizes and genomes, viruses can be very powerful machines responsible for specific changes in cell regulation and function. Certain viruses that seek monocytes/macrophages frequently possess the ability to change cellular decisions regarding fate and decoy apoptosis and can alter morphology and polarize cells. These abilities, therefore, lead to cytokine/chemokine expression modification and escape from the immune system. The basic biology of viral reservoirs, knowledge of viral transmission systems and "backup" cells will be of great help in the advancement of effective viral therapies, allowing the development of potential life-saving techniques. Recent achievements in this area of investigation are also summarized in this review.

\section{Monocytes and Tissue Macrophages}

Macrophages are key cells of the immune system that orchestrate various physiological and pathological processes of an infectious and non-infectious nature. Macrophages were discovered by Russian zoologist Élie Metchnikoff in the late nineteenth century [4]. Initial discovery focused on the phagocytic activity of macrophages, which is important for host defence against infection and for maintenance of 'housekeeping' functions such as the removal of apoptotic cells and remodelling of the extracellular matrix [5]. Accumulating data has revealed that macrophages play a valuable role in 
systemic metabolism, cold adaptation, tissue homeostasis and development, the pathology of chronic inflammation, cancer, cardio-metabolic disorders and neurodegeneration [6].

All macrophages take various forms (with various names) throughout the body and are designated as histiocytes, Kupffer cells, Hofbauer cells, alveolar macrophages and microglia, among others. Despite heterogeneity, tissue-resident macrophages are derived from three sources: yolk sac, foetal liver and hematopoietic stem cells in the bone marrow [7].

Major biological activities of macrophage include phagocytosis, antigen presentation and the release of cytokine (pro-inflammatory/anti-inflammatory mediators), antibacterial substances and enzymes that remodel the extracellular matrix [8]. Macrophages attract and activate other cells of the adaptive immune system, in particular $\mathrm{T}$ cells, to sites of chronic inflammation. Further, macrophages are able to sense the time at which an injury is terminated and thus start the resolution process of inflammation and the control of the healing phase [9].

Depending on the timeframe and tissue, several intrinsic, extrinsic and tissue-environmental stimuli promote monocyte polarization. Specific stimuli include cytokines, growth factors, prostaglandins, fatty acids and pathogen-derived molecules [10]. $M \phi$ phenotypes represent a wide spectrum of activation states which are not restricted to the classical M1 (classically IFN- $\gamma$-activated) and M2 (alternatively IL-4-activated) subtypes [9]. M1-like polarized macrophages are characterized by a high level of phagocytic activity and an elevated secretion of proinflammatory cytokines and chemokines, which induces Th1 response activation and facilitates complement-mediated phagocytosis and type I inflammation. M1-like polarized macrophages also carry out phagocytosis of microorganism and matrix debris in the early phases of healing and have high antigen presentation capacity [10]. In several infections, M1 polarization favours virus establishment, as shown for HIV-1, which induces acute inflammation and promotes the recruitment of monocytes and $\mathrm{T}$ cells on site [11]. M2 macrophages comprise a wide range of macrophage subtypes, including tumour-associated macrophages, healing macrophages and macrophages found in chronic inflammatory conditions; thus, they play a crucial role in carcinogenesis and inflammation-dependent diseases (e.g., neurodegenerative disorders) [12]. M2-like macrophages modulate the Th2 response by producing anti-inflammatory mediators, leading to neutrophil, monocyte and $\mathrm{T}$ lymphocyte recruitment; they are highly endocytic and partially phagocytic; they are involved in a variety of functions including repair mechanisms, homeostasis, metabolic processes and pathogenesis. Macrophages possess high plasticity. Data from several studies has demonstrated that macrophages switch their polarization upon changes in the micro environmental conditions from M1 to M2 and vice versa [10].

Both acute and chronic inflammatory programming of macrophages can be utilized by viruses for their dissemination, replication and survival. M1-polarized cells are susceptible to viruses and they recruit other cell populations to the inflammation site, which favours virus transmission and dissemination. By contrast, M2 macrophages are involved in chronic disease and ensure permissiveness and the tissue distribution of viruses, forming a life-long reservoir of infection able to be activated and replenished upon conducive conditions.

\section{Viruses Infect Monocytes and Macrophages}

The first reports on the topic of myeloid cell response and reaction to viruses date back to $1978[13,14]$. The questions of permissiveness and the potential of monocytes and macrophages to be a reservoir for infectious agents was and still is, very intriguing to scientists. Knowledge in this area is interesting because it can lead to the basic understanding of many processes, such as virus-cell interactions that are receptor-based, cell-to-cell transmission upon infection, persistence, genetic changes of cell machinery and therapy applications to certain cohorts of patients. Circulating monocytes and macrophages play one of the most important roles in the protection of the organism against viral infection. Through use of animal models and viruses associated with lethal disease, researchers have made the surprising discovery that these cells can be defined as part of a permissive system, carrying special "parcels" that 
assist viral spread into susceptible sites (e.g., the central nervous system) and virus dissemination to other cells [14-16]. Later experiments on human infection (tissue-derived cells, post-mortem tissue samples, human cell cultures) revealed many spectacular functions of monocytes/macrophages and the diverse adaptations of viruses to this particular cell system [17-20]. Today, an important role of monocytes/macrophages has been shown for the persistence or spread of more than 35 viruses belonging to 13 different families. Among them are ssRNA and dsDNA agents, which lead to a variety of diseases including formidable immunodeficiency syndrome, virus-induced microcephaly and Guillain-Barré syndrome [3,18]. Types of viruses, species affected, models and organisms used for experiments, monocyte/macrophage reaction and cell polarization changes upon infection and other valuable information are summarized in Table 1 and depicted in Figure 1 . These data concern humans [17,19,21,22], mammals in general [23,24] and amphibian species [25].

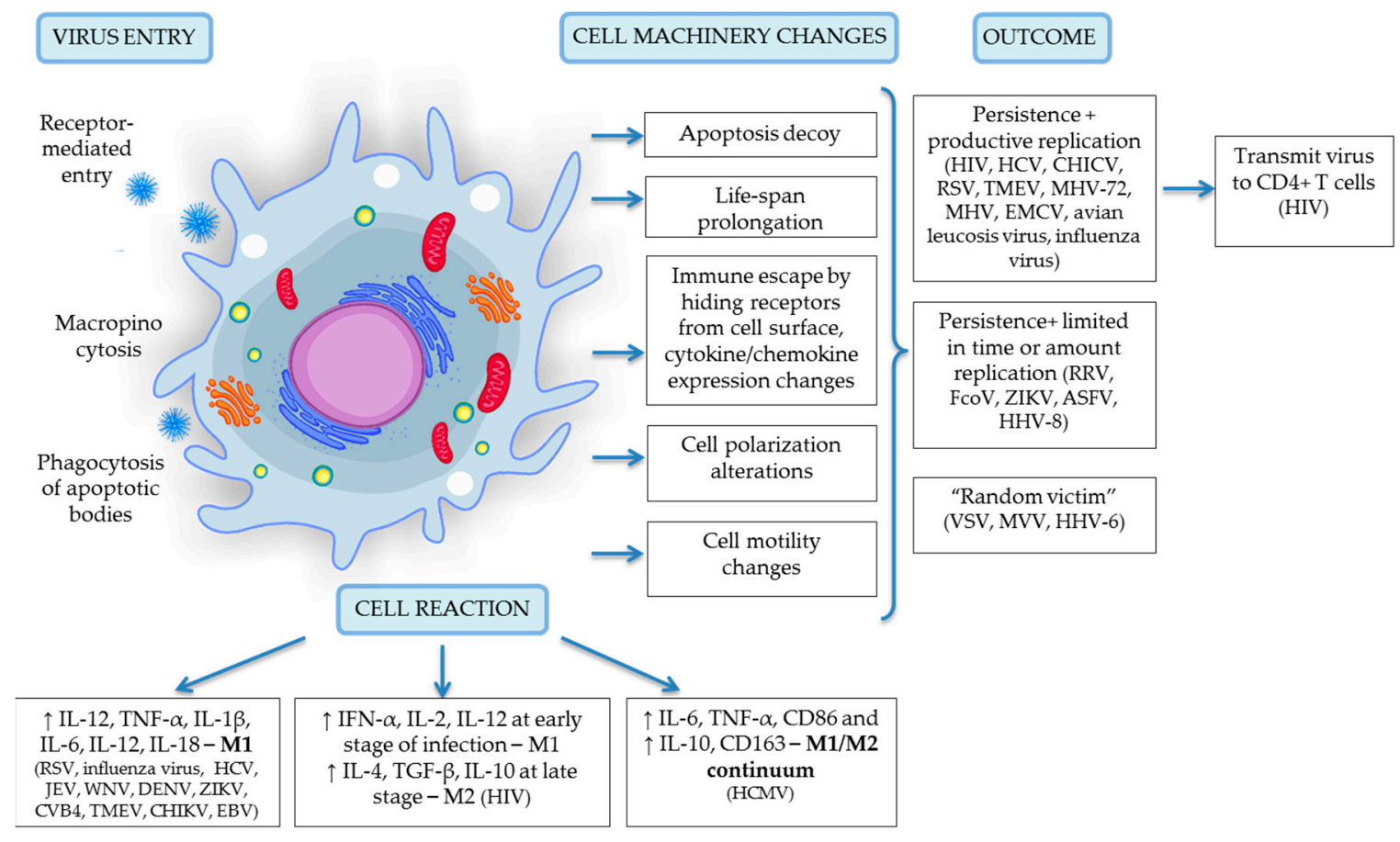

Figure 1. A schematic representation of virus entry, cell reaction and machinery changes and viral outcome upon infection specific for the monocyte/macrophage system. Details of depicted interactions are discussed in detail in the text above. 
Table 1. Viruses affecting monocyte/macrophage cells.

\begin{tabular}{|c|c|c|c|c|c|c|c|c|c|c|}
\hline & Virus & Family & Genome & Host & Disease & Model & Type of Cells & $\begin{array}{l}\text { Virus Persistence and } \\
\text { Survival in M } \phi \\
\end{array}$ & Reaction of $\mathrm{M} \Phi$ & Reference \\
\hline 1 & $\begin{array}{l}\text { Respiratory } \\
\text { syncytial virus } \\
\text { (RSV) }\end{array}$ & Paramyxoviridae & (-) ssRNA & Human & $\begin{array}{l}\text { Bronchiolitis and } \\
\text { pneumonia, } \\
\text { severe acute } \\
\text { lower-respiratory } \\
\text { tract disease in } \\
\text { children }\end{array}$ & $\begin{array}{l}\text {-In vitro model of } \\
\text { persistently } \\
\text { RSV-infected M } \phi \text {-like } \\
\text { cell line P388D1 (M } \phi \mathrm{P}) \\
\text {-RAW264.7 M } \phi \\
\text {-Human tissue M } \phi\end{array}$ & $\begin{array}{l}\text {-Murine } \mathrm{M} \phi \text {-cell } \\
\text { line } \\
\text {-Human alveolar } \\
\mathrm{M} \phi\end{array}$ & $\begin{array}{l}\text {-RSV persist in in vitro model } \\
\text { for over } 87 \text { passages. } \\
\text {-Alveolar M } \phi \text { support a } \\
\text { productive RSV infection } \\
\text { in vitro at least for } 25 \text { days. } \\
\text {-Lack of response of infected } \\
\text { M } \phi \text { to the IFN-beta. }\end{array}$ & $\begin{array}{l}\text {-Infected } \mathrm{M} \phi \text { produces high level of } \\
\text { proinflammatory cytokines (class II } \\
\text { HLA-DR, IL-1ß and } \\
\text { TNF } \alpha \text {-immunofluorescent staining). } \\
\text {-Reduced cytotoxic effect in } M \phi P \text { cells } \\
\text { (activation of caspase- } 9 \text { along with } \\
\text { impairment of caspase- } 8 \text { activity). }\end{array}$ & [26-28] \\
\hline 2 & Influenza virus & Orthomyxoviridat & $(-)$ ssRNA & Human & Influenza & $\begin{array}{l}\text {-Autopsies } \\
\text {-In vitro model, } \\
\text { BALB/c mice } \\
\text {-Human primary M } \phi\end{array}$ & $\begin{array}{l}\text {-Mouse lung M } \phi \\
\text {-Human primary } \\
\mathrm{M} \phi\end{array}$ & $\begin{array}{l}\text {-Low virulence persistence of } \\
\text { influenza virus in the alveolar } \\
\text { M } \phi . \\
\text {-Productive replication of } \\
\text { H5N1 virus in alveolar M } \phi \text {. }\end{array}$ & $\begin{array}{l}\text {-Infected M } \phi \text { produces high level } \\
\text { IL-1ß, IL-6, TNF } \alpha \text { (flow cytometry). } \\
\text {-M } \phi \text { demonstrated no cytopathic } \\
\text { changes (visual examination of } \\
\text { monolayers). }\end{array}$ & [29-31] \\
\hline 3 & $\begin{array}{l}\text { Vesicular stomatitis } \\
\text { virus (VSV) }\end{array}$ & Rhabdoviridae & $(-)$ ssRNA & $\begin{array}{l}\text { Insects, cattle, } \\
\text { horses, pigs } \\
\text { (zoonotic virus) }\end{array}$ & $\begin{array}{l}\text { Flu-like illness in } \\
\text { infected humans }\end{array}$ & $\mathrm{BALB} / \mathrm{c}$ mice & $\begin{array}{l}\text { Tissue M } \phi \text { (lymph } \\
\text { nodes, lungs, } \\
\text { spleens, liver, } \\
\text { muscle) }\end{array}$ & $\begin{array}{l}\text {-M } \phi \text { are not the major } \\
\text { reservoirs of VSV gRNA at late } \\
\text { times ( }>60 \text { days). } \\
\text {-No replication in } \mathrm{M} \phi .\end{array}$ & (1) & [32] \\
\hline 4 & $\begin{array}{l}\text { Porcine } \\
\text { reproductive and } \\
\text { respiratory } \\
\text { syndrome virus } \\
\text { (PRRSV) } \\
\end{array}$ & Arteriviridae & $(+)$ ssRNA & Pig & $\begin{array}{l}\text { Respiratory } \\
\text { syndrome }\end{array}$ & Pig & $\begin{array}{l}\text { Porcine alveolar } \\
\mathrm{M} \phi\end{array}$ & $\begin{array}{l}\text { Productive replication of virus } \\
\text { in alveolar } \mathrm{M} \phi \text { in in vivo } \\
\text { model. }\end{array}$ & $\begin{array}{l}\text { In vitro infected } \mathrm{M} \phi \text { are protected } \\
\text { against complement-mediated cell } \\
\text { lysis. }\end{array}$ & [23] \\
\hline 5 & $\begin{array}{l}\text { Feline coronavirus } \\
(\mathrm{FCoV})\end{array}$ & Coronaviridae & (+) ssRNA & Cats & $\begin{array}{l}\text { Infectious } \\
\text { peritonitis }\end{array}$ & $\begin{array}{l}\text { Specific-pathogen-free } \\
\text { cats }\end{array}$ & Tissue M $\phi$ & $\begin{array}{l}\text { Virus persists in tissue } \mathrm{M} \phi \\
\text { (mostly in colon) up to } 80 \text { days } \\
\text { after inoculation. }\end{array}$ & NS & [33] \\
\hline 6 & $\begin{array}{l}\text { Mouse hepatitis } \\
\text { virus (MHV) }\end{array}$ & Coronaviridae & $(+)$ ssRNA & Mouse & $\begin{array}{l}\text { Model of multiple } \\
\text { sclerosis }\end{array}$ & Mouse & $\begin{array}{l}\text { Mouse peritoneal } \\
\text { M } \phi\end{array}$ & $\begin{array}{l}\text {-M } \phi \text { disseminate virus into } \\
\text { CNS. } \\
\text {-Mouse peritoneal M } \phi \text { are } \\
\text { permissive for virus. Virus } \\
\text { persists in the cells up to } 8 \\
\text { months. }\end{array}$ & $\begin{array}{l}\text { Infected M } \phi \text { express CCR1, CCR2 and } \\
\text { CCR5 that lead to recruitment of } M \phi \\
\text { into the CNS. }\end{array}$ & {$[34,35]$} \\
\hline 7 & $\begin{array}{l}\text { Classical swine } \\
\text { fever virus (CSFV) }\end{array}$ & Flaviviridae & $(+)$ ssRNA & Swine & Lethal fever & $\begin{array}{l}\text { Pig tissue monocytes } \\
\text { and } \mathrm{M} \phi\end{array}$ & $\begin{array}{l}\text { Tissue monocytes } \\
\text { and M } \phi\end{array}$ & $\begin{array}{l}\text { Productive replication of virus } \\
\text { in alveolar } \mathrm{M} \phi \text { and monocytes. }\end{array}$ & NS & {$[36]$} \\
\hline 8 & $\begin{array}{l}\text { Hepatitis } \mathrm{C} \text { virus } \\
\text { (HCV) }\end{array}$ & Flaviviridae & $(+)$ ssRNA & Human & Hepatitis C & $\begin{array}{l}\text {-Patients } \\
\text {-Cell culture } \\
(\text { THP-1)/tissue M } \phi\end{array}$ & $\begin{array}{l}\text {-PBMC, M } \phi \text { culture } \\
\text { (THP-1), microglial } \\
\text { M } \phi \text { (CD68+ and } \\
\text { CD45+) }\end{array}$ & $\begin{array}{l}\text {-HCV persists in liver } \mathrm{M} \phi \text { and } \\
\text { lymphocytes for up to } 9 \text { years. } \\
\text {-Productive replication of virus } \\
\text { in a relatively non-specific } \\
\text { manner in } M \phi .\end{array}$ & $\begin{array}{l}\text { Infected } M \phi / \text { microglial cells express } \\
\text { higher level of IL- } 1 \alpha, \text { TNF } \alpha \text {, IL-1 } \beta \text {, } \\
\text { IL-12, IL-18 (PCR analysis). }\end{array}$ & {$[37,38]$} \\
\hline
\end{tabular}


Table 1. Cont.

\begin{tabular}{|c|c|c|c|c|c|c|c|c|c|c|}
\hline & Virus & Family & Genome & Host & Disease & Model & Type of Cells & $\begin{array}{l}\text { Virus Persistence and } \\
\text { Survival in } M \phi\end{array}$ & Reaction of $\mathrm{M} \Phi$ & Reference \\
\hline 9 & $\begin{array}{l}\text { Japanese } \\
\text { encephalitis virus } \\
\text { (JEV), West Nile } \\
\text { virus (WNV), } \\
\text { Dengue virus } \\
\text { (DENV) }\end{array}$ & Flaviviridae & (+) ssRNA & Human & Neurotropic, CNS & $\begin{array}{l}\text {-Raw264.7 cells } \\
\text {-BALB/c mice } \\
\text {-Macaques }\end{array}$ & $\begin{array}{l}\text {-Murine } \\
\text { monocyte-derived } \\
\text { M } \phi \text { (MDM) } \\
\text {-Perivascular M } \phi\end{array}$ & 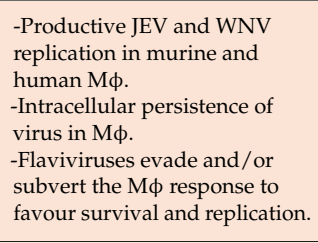 & $\begin{array}{l}\text {-Infected Mф produce TNF- } \alpha \text {, IL-6, } \\
\text { IFN- } \alpha \text { and CCL2, inducible nitric } \\
\text { oxide synthase (iNOS) and } \\
\text { nitrotyrosine (NT) in response to JEV } \\
\text { in vitro (immunofluorescent staining, } \\
\text { IIN bioassay, Cytometric Bead Array). } \\
\text {-Both human and rodent microglia } \\
\text { produce CCL2, CXCL9 and CXCL10 } \\
\text { upon JEV exposure (flow cytometry). }\end{array}$ & {$[22,39,40]$} \\
\hline 10 & Zika virus (ZIKV) & Flaviviridae & (+) ssRNA & Human & $\begin{array}{l}\text { Foetal brain } \\
\text { abnormalities and } \\
\text { microcephaly, } \\
\text { Guillain-Barré } \\
\text { syndrome }\end{array}$ & $\begin{array}{l}\text { Primary human } \\
\text { placental } \mathrm{M} \phi\end{array}$ & $\begin{array}{l}\text { Human placental } \\
\text { M } \phi \text { (Hofbauer cells, } \\
\text { HC) }\end{array}$ & $\begin{array}{l}\text {-Hofbauer cells are permissive } \\
\text { to productive ZIKV infection. }\end{array}$ & $\begin{array}{l}\text { Infected HCs produce high level of } \\
\text { IFN } \alpha \text {, IL-6, chemokines MCP-1 and } \\
\text { IP-10 (flow cytometry). }\end{array}$ & [41] \\
\hline 11 & $\begin{array}{l}\text { Coxsackieviruses } \\
\text { (CVB4, CVB3) }\end{array}$ & Picornaviridae & (+) ssRNA & Human & $\begin{array}{l}\text {-Type } 1 \text { diabetes; } \\
\text {-Myocarditis }\end{array}$ & $\begin{array}{l}\text {-Human MDM; } \\
\text {-Mouse }\end{array}$ & $\begin{array}{l}\text {-MDM } \\
\text {-Pancreas M } \phi \\
\text {-Myocardial M } \phi \\
\text { (activation of } \\
\text { JAK1-STAT1 and } \\
\text { JAK3-STAT6 } \\
\text { pathways) }\end{array}$ & $\begin{array}{l}\text {-CVB4 replicates and persist in } \\
\text { MDM and tissue M } \phi \text {. }\end{array}$ & $\begin{array}{l}\text {-CVB4-infected M } \phi \text { produce high } \\
\text { levels of pro-inflammatory cytokines } \\
\text { (IL-6 and TNF } \alpha \text {-ELISA) in both } \\
\text { M-CSF MDM and GM-CSF MDM } \\
\text { cultures. } \\
\text {-Virus infected pancreas M } \phi \text { showed } \\
\text { M1 polarization } \\
\text { (Ly-6C+/CD15+-flow cytometry). } \\
\text {-M } \phi \text { polarization depends on gender } \\
\text { (M1 phenotype detected in males and } \\
\text { M2a phenotype in females). }\end{array}$ & [42-44] \\
\hline 12 & $\begin{array}{l}\text { Encephalomyocarditis } \\
\text { virus (EMCV) }\end{array}$ & Picornaviridae & (+) ssRNA & Rodents, pigs & $\begin{array}{l}\text {-Lethal acute } \\
\text { myocarditis, fatal } \\
\text { illness in primates } \\
\text { and captive wild } \\
\text { animals }\end{array}$ & $\begin{array}{l}\text {-Mouse tissue } \mathrm{M} \phi \\
-\mathrm{RAW} 264.7 \text {, naive } \\
\text { mouse } \mathrm{M} \phi\end{array}$ & $\begin{array}{l}\text {-Tissue } \mathrm{M} \phi \text { (brain, } \\
\text { heart, pancreas, } \\
\text { kidney, Peyer's } \\
\text { patches, spleen, } \\
\text { lung and thymus) }\end{array}$ & $\begin{array}{l}\text {-Virus persists in the thymus } \\
\text { M } \phi \text { up to } 62 \text { days post } \\
\text { infection. } \\
\text {-Productive viral replication in } \\
\text { M } \phi \text {. }\end{array}$ & $\begin{array}{l}\text { EMCV activates pro-inflammatory } \\
\text { signalling in M } \phi \text { within minutes } \\
\text { during virus infection and type I IFNs } \\
\text { response afterwards. }\end{array}$ & {$[24,45]$} \\
\hline 13 & $\begin{array}{l}\text { Theiler's murine } \\
\text { encephalomyelitis } \\
\text { virus (TMEV) }\end{array}$ & Picornaviridae & (+) ssRNA & Mouse & $\begin{array}{l}\text { Skeletal muscle } \\
\text { infection and } \\
\text { inflammation, } \\
\text { encephalomyelitis } \\
\text { and multiple } \\
\text { sclerosis, epilepsy }\end{array}$ & $\begin{array}{l}\text {-J774.1 M } \phi \\
\text {-RAW264.7 M } \phi \text { cell line } \\
\text {-C57BL/6 (B6) mouse } \\
\text {-Primary peritoneal M } \phi\end{array}$ & $\begin{array}{l}\text { M } \phi \text { cell lines, tissue } \\
\mathrm{M} \phi\end{array}$ & $\begin{array}{l}- \text { TMEV persists in M } \phi \text { during } \\
\text { the chronic demyelinating } \\
\text { phase. } \\
\text {-Productive replication of } \\
\text { TMEV in M } \phi \text {. }\end{array}$ & $\begin{array}{l}\text {-Infected M } \phi \text { in wild type animals } \\
\text { showed M1 polarization } \\
\text { (CD45+CD11b+Lycc+) while } \\
\text { muscle-infiltrating M } \phi \text { displayed an } \\
\text { immature phenotype in } \\
\text { SHP-1-deficient mice (flow cytometry). } \\
\text {-Infected peritoneal M } \phi \text { produce high } \\
\text { level of IFN } \alpha \text { and TNF } \alpha \text { (ELISA). } \\
\text {-TMEV replication cause restricted } \\
\text { induced apoptosis of } M \phi \text {. }\end{array}$ & {$[16,46-48]$} \\
\hline
\end{tabular}


Table 1. Cont.

\begin{tabular}{|c|c|c|c|c|c|c|c|c|c|c|}
\hline & Virus & Family & Genome & Host & Disease & Model & Type of Cells & $\begin{array}{c}\text { Virus Persistence and } \\
\text { Survival in } M \phi \\
\end{array}$ & Reaction of $M \phi$ & Reference \\
\hline 14 & $\begin{array}{l}\text { Chikungunya } \\
\text { alphavirus (CHIKV) }\end{array}$ & Togaviridae & (+) ssRNA & Human & $\begin{array}{l}\text { Articular disease/ } \\
\text { myalgia }\end{array}$ & $\begin{array}{l}\text {-Cell line } \\
\text {-Patients } \\
\text {-Immunocompetent } \\
\text { cynomolgus macaques }\end{array}$ & $\begin{array}{l}\text {-RAW264.7 M } \phi \\
\text {-Perivascular } \\
\text { synovial M } \phi\end{array}$ & $\begin{array}{l}\text {-Productive replication of } \\
\text { CHIKV in RAW264.7 M } \phi \text { but } \\
\text { in in vivo--low viral } \\
\text { replication and release of } \\
\text { non-infectious viral particles. } \\
\text {-Virus persists in the cells after } \\
18 \text { months of chronic disease. } \\
\text {-M } \phi \text { are the main cellular } \\
\text { reservoirs during the late } \\
\text { stages of CHIKV infection } \\
\text { in vivo. }\end{array}$ & $\begin{array}{l}\text { No induced apoptosis in infected } \\
\text { RAW264.7 cells. }\end{array}$ & {$[19,49,50]$} \\
\hline 15 & $\begin{array}{l}\text { Sindbis virus } \\
\text { (SINV), Mayaro } \\
\text { virus (MAYV), } \\
\text { O'nyong-nyong } \\
\text { virus (ONNV) and } \\
\text { Barmah Forest virus } \\
\text { (BFV), Ross River } \\
\text { virus (RVV), CHIKV }\end{array}$ & Togaviridae & (+) ssRNA & $\begin{array}{l}\text { Mosquitoes, } \\
\text { marsupials, } \\
\text { humans }\end{array}$ & $\begin{array}{l}\text { Articular } \\
\text { disease/myalgia }\end{array}$ & $\begin{array}{l}\text {-Patients } \\
\text {-RAW } 264.7 \mathrm{M \phi}\end{array}$ & $\begin{array}{l}\text {-RAW264.7 M } \phi \\
\text {-Perivascular } \\
\text { synovial M } \phi\end{array}$ & $\begin{array}{l}\text {-Productive viral gene } \\
\text { expression in synovial } \mathrm{M} \phi \text {. } \\
\text {-RRV persist in RAW } 264.7 \mathrm{M} \phi \\
\text { up to } 170 \text { days in vitro. }\end{array}$ & $\begin{array}{l}\text {-Infected M } \phi \text { displayed M1 } \\
\text { polarization (CD68)) in vivo. } \\
\text {-CHIKV infection cause induced } \\
\text { apoptosis in vivo leading to viral } \\
\text { dissemination into apoptotic blebs. } \\
\text {-CHIKV-infected RAW264.7 M } \phi \\
\text { showed high production of TNF- } \alpha \text {, } \\
\text { IL-6 and GM-CSF (QPCR). } \\
\text {-RRV-infected M } \phi \text { in vitro displayed } \\
\text { restricted cytopathic effects. }\end{array}$ & {$[20,51-53]$} \\
\hline 16 & Avian oncoviruses & Retroviridae & ssRNA-RT & Many species & Cancer & Chicken & Tissue M $\phi, \mathrm{MDM}$ & $\begin{array}{l}\text {-Avian leukosis viruses persist } \\
\text { in } M \phi \text { of peripheral blood up } \\
\text { to about } 3 \text { years. } \\
\text {-Avian sarcoma viruses were } \\
\text { never found in } M \phi \text {. }\end{array}$ & 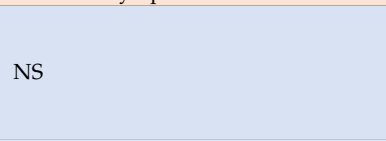 & [14] \\
\hline 17 & $\begin{array}{l}\text { Murine leukaemia } \\
\text { viruses (MuLVs) }\end{array}$ & Retroviridae & ssRNA-RT & Mouse & $\begin{array}{l}\text { A model for } \\
\text { non-inflammatory } \\
\text { degeneration of } \\
\text { the central } \\
\text { nervous system }\end{array}$ & $\mathrm{BALB} / \mathrm{c}$ and $\mathrm{C} 3 \mathrm{H}$ mice & Tissue M $\phi$ & $\begin{array}{l}\text { Virus infects } M \phi / \text { microglia } \\
\text { and persists during later stages } \\
\text { ( } 8 \text { weeks after infection). }\end{array}$ & NS & [15] \\
\hline 18 & $\begin{array}{l}\text { Ovine lentivirus } \\
\text { OvLV }\end{array}$ & Retroviridae & ssRNA-RT & Sheep & $\begin{array}{l}\text { Encephalitis and } \\
\text { chronic } \\
\text { pneumonitis }\end{array}$ & Lamb & Tissue $\mathrm{M} \phi$ & $\begin{array}{l}\text { OvLV variants persist in } \\
\text { alveolar } \mathrm{M} \phi .\end{array}$ & NS & [54] \\
\hline 19 & $\begin{array}{l}\text { Human } \\
\text { immunodeficiency } \\
\text { virus (HIV), Simian } \\
\text { immunodeficiency } \\
\text { virus (SIV) }\end{array}$ & Retroviridae & ssRNA-RT & Human & $\begin{array}{l}\text { Immune } \\
\text { deficiency } \\
\text { syndrome (AID), } \\
\text { cancer }\end{array}$ & $\begin{array}{l}\text { Human (U937, THP-1) } \\
\text { and mouse cell lines, } \\
\text { humanand monkey, } \\
\text { macaque tissue M } \phi\end{array}$ & $\begin{array}{l}\text { MDM, monocytes, } \\
\text { tissue } \mathrm{M} \phi\end{array}$ & $\begin{array}{l}\text {-CD14+CD16+ monocytes are } \\
\text { permissive to productive } \\
\text { infection. } \\
\text {-M } \phi \text { serves as a major reservoir } \\
\text { for HIV. } \\
\text {-Infected M } \phi \text { escape immune } \\
\text { response. } \\
\text {-Infected M } \phi \text { showed impaired } \\
\text { phagocytic activity. } \\
\text {-M } \phi \text { dissiminate HIV to CD4+ } \\
\text { T cells and central nervous } \\
\text { system (“Trojan horse } \\
\text { hypothesis"). }\end{array}$ & 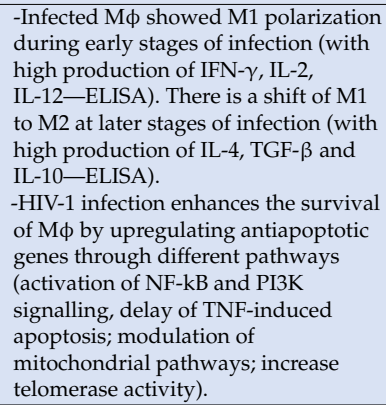 & {$[18,55,56]$} \\
\hline
\end{tabular}


Table 1. Cont

\begin{tabular}{|c|c|c|c|c|c|c|c|c|c|c|}
\hline & Virus & Family & Genome & Host & Disease & Model & Type of Cells & $\begin{array}{l}\text { Virus Persistence and } \\
\text { Survival in } M \Phi\end{array}$ & Reaction of M $\phi$ & Reference \\
\hline 20 & Maedi-visna (MVV) & Retroviridae & ssRNA-RT & Sheep & $\begin{array}{l}\text { Fatal } \\
\text { lymphoproliferative } \\
\text { disease }\end{array}$ & Sheep & $\begin{array}{l}\text { Bone marrow } \\
\text { monocytes, PBMC }\end{array}$ & $\begin{array}{l}\text { Limited virus replication in } \\
\text { bone marrow monocytes. }\end{array}$ & NS & [57] \\
\hline 21 & $\begin{array}{l}\text { African swine fever } \\
\text { virus (ASFV) }\end{array}$ & Asfarviridae & dsDNA & $\begin{array}{l}\text { Pig, warthogs, } \\
\text { bushpigs, soft } \\
\text { ticks }\end{array}$ & $\begin{array}{l}\text { Lethal } \\
\text { haemorrhagic } \\
\text { fever }\end{array}$ & $\begin{array}{l}\text {-Pig } \\
\text {-Porcine alveolar M } \phi\end{array}$ & $\begin{array}{l}\text {-Cell culture } \\
\text { derived from bone } \\
\text { marrow, PBMC } \\
\text {-Alveolar and bone } \\
\text { marrow cells }\end{array}$ & $\begin{array}{l}\text {-Virus persists in tissue } \mathrm{M} \phi . \\
\text {-Moderate virus replication } \\
\text { continued for at least } 3 \text { months } \\
\text { in alveolar and bone marrow } \\
\text { M } \phi \text { s. }\end{array}$ & $\begin{array}{l}\text {-Virus caused cytotoxic effect within } \\
2-3 \text { days in monocytes but not in } \mathrm{M} \phi \\
\text { (visual examination of monolayers). } \\
\text {-Virus leads to full morphological } \\
\text { differentiation of } \mathrm{M} \phi \text { (visual } \\
\text { examination of cell morphology). }\end{array}$ & {$[13,58]$} \\
\hline 22 & $\begin{array}{l}\text { Bovine } \\
\text { herpesvirus-4 } \\
\text { (BHV-4) }\end{array}$ & Herpesviridae & dsDNA & Cattle, rabbits & $\begin{array}{l}\text { Endometritis, } \\
\text { vulvovaginitis } \\
\text { and mastitis }\end{array}$ & $\begin{array}{l}\text { Bovine M申 cell line } \\
\text { (BOMAC). }\end{array}$ & Cell culture & $\begin{array}{l}\text {-Virus cause cell death of the } \\
\text { majority of BOMAC cells and } \\
\text { persists in surviving cells. }\end{array}$ & 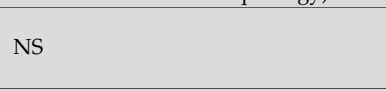 & [59] \\
\hline 23 & $\begin{array}{l}\text { Cytomegalovirus } \\
\text { (CMV) }\end{array}$ & Herpesviridae & dsDNA & Human & $\begin{array}{l}\text { Chronical } \\
\text { inflammation, } \\
\text { cardiovascular } \\
\text { diseases, some } \\
\text { types of cancers }\end{array}$ & $\begin{array}{l}\text {-Murine } \\
\text { cytomegalovirus model } \\
\text { (MCMV), } \\
\text { MDM/Allo-MDM }\end{array}$ & $\begin{array}{l}\text {-Human monocytes } \\
\text {-MDM }\end{array}$ & $\begin{array}{l}\text {-Productive replication of CMV } \\
\text { in human M } \phi \text { up to } 16 \text { weeks } \\
\text { but not monocytes. } \\
\text {-Monocytes disseminate virus } \\
\text { in organism. }\end{array}$ & $\begin{array}{l}\text {-HCMV induces specific phenotype } \\
\text { within M1/M2 continuum (skewed } \\
\text { towards M1). Simultaneous expression } \\
\text { of M1-associated molecules (IL-6, } \\
\text { TNF- } \alpha, \text { CD86) and M2-associated } \\
\text { molecules (IL-10 and CD163) by } \\
\text { infected M } \phi \text {. Data analysed using } \\
\text { PCR, flow cytometry (M1 cells were } \\
\text { CD68+, M2-CD163+), microarray } \\
\text { analysis for more than } 2000 \text { genes. } \\
\text {-Decoy of induced apoptosis of } \\
\text { infected monocytes due to prolonged } \\
\text { expression of the anti-apoptotic } \\
\text { molecule, Mcl-1. } \\
\text {-Infected cells escape the cellular } \\
\text { antiviral pro-apoptotic response due to } \\
\text { specific cytokine/chemokine } \\
\text { expression (the "Goldilocks" } \\
\text { phenomenon). } \\
\text {-Infected cells utilize EGFR receptor } \\
\text { and integrins. }\end{array}$ & $\begin{array}{l}\text { Review } \\
{[17,60]}\end{array}$ \\
\hline 24 & $\begin{array}{l}\text { Epstein-Barr virus } \\
\text { infection (EBV) }\end{array}$ & Herpesviridae & dsDNA & Human & $\begin{array}{l}\text { Inflammation, } \\
\text { some types of } \\
\text { cancers }\end{array}$ & $\begin{array}{l}\text { Human cancer tissues, } \\
\text { human smears, rhesus } \\
\text { macaques, M } \phi \text { culture } \\
\text { (RAW } 264.7 \text { cells), } \\
\text { Balb } / \text { c and IL-10KO } \\
\text { mice. }\end{array}$ & $\begin{array}{l}\text { MDM, tissue M } \phi \text {, } \\
\text { submucosal } \\
\text { monocytes, } \\
\text { tumour-associated } \\
\text { M } \phi \text { (TAMs) }\end{array}$ & $\begin{array}{l}\text {-EBV replicates in M } \phi . \\
\text {-Monocytes disseminate virus } \\
\text { in organism. }\end{array}$ & $\begin{array}{l}\text {-Infected M } \phi \text { produce high level of } \\
\text { IL-8, MCP-1 due to TLR9 and TLR-2 } \\
\text { activation (ELISA). } \\
\text {-Monocytes produce high level of } \\
\text { IFN } \alpha \text { in response to EBV (ELISA). } \\
\text {-IL-10-dependent M2 polarization of } \\
\text { infected TAMs (ELISA). }\end{array}$ & $\begin{array}{l}\text { A book [61], } \\
\text { review [62] }\end{array}$ \\
\hline 25 & $\begin{array}{l}\text { Human herpesvirus } \\
6 \text { (HHV-6) }\end{array}$ & Herpesviridae & dsDNA & Human & Multiple sclerosis & Human & -PBMC & $\begin{array}{l}\text {-Latent persistence of HHV-6 in } \\
\text { M } \phi \text { s for more than } 1 \text { month. }\end{array}$ & $\begin{array}{l}\text { Selective downregulation of IL-12 in } \\
\text { infected M } \phi \text { (ELISA), which is not } \\
\text { dependent upon productive viral } \\
\text { infection. }\end{array}$ & [63-65] \\
\hline
\end{tabular}


Table 1. Cont

\begin{tabular}{|c|c|c|c|c|c|c|c|c|c|c|}
\hline & Virus & Family & Genome & Host & Disease & Model & Type of Cells & $\begin{array}{l}\text { Virus Persistence and } \\
\text { Survival in } M \Phi\end{array}$ & Reaction of $M \phi$ & Reference \\
\hline 26 & $\begin{array}{l}\text { Kaposi's } \\
\text { sarcoma-associated } \\
\text { herpesvirus KSHV } \\
\text { (HHV-8) }\end{array}$ & Herpesviridae & dsDNA & Human & Cancer & $\begin{array}{l}\text {-Tumour } \\
\text { microenvironment, cell } \\
\text { culture. } \\
\text {-MDM } \\
\text {-Prostate cancer } \\
\text { samples }\end{array}$ & $\begin{array}{l}\text { Tissue M } \phi \text {, RAW } \\
264.7 \text { cells }\end{array}$ & $\begin{array}{l}\text {-HHV-8 led to production of } \\
\text { viral proteins in intralesional } \\
\text { M } \phi \text {, with little production of } \\
\text { viral DNA. } \\
\text {-Virus persists in a latent form } \\
\text { in } M \phi / \text { monocytes. } \\
\text {-Lytic gene expression in } M \phi \text { in } \\
\text { prostate stroma. }\end{array}$ & $\begin{array}{l}\text { KSHV miRNAs protect } \mathrm{M} \phi \text { from cell } \\
\text { death through the upregulation of } \\
\mathrm{xCT} \text {. }\end{array}$ & [66-68] \\
\hline 27 & $\begin{array}{l}\text { Murine herpesvirus } \\
72 \text { (MHV-72) }\end{array}$ & Herpesviridae & dsDNA & Mouse & $\begin{array}{l}\text { Acute infection of } \\
\text { lung epithelial } \\
\text { cells }\end{array}$ & Balb/c mice & $\begin{array}{l}\text { Lung mononuclear } \\
\text { cells }\end{array}$ & $\begin{array}{l}\text { Virus persists in alveolar and } \\
\text { peritoneal lung mononuclear } \\
\text { cells and } \mathrm{M} \phi \text { of peripheral } \\
\text { blood up to } 8 \text { months. }\end{array}$ & NS & [69] \\
\hline & $\begin{array}{l}\text { Varicella-zoster } \\
\text { virus (VZV), simian } \\
\text { varicella virus } \\
\text { (SVV) }\end{array}$ & Herpesviridae & dsDNA & $\begin{array}{l}\text { Human, } \\
\text { nonhuman } \\
\text { primates }\end{array}$ & $\begin{array}{l}\text { Varicella-zoster, } \\
\text { "multiple } \\
\text { sclerosis-like" } \\
\text { pathology }\end{array}$ & $\begin{array}{l}\text {-Human ganglia. } \\
\text {-Rhesus macaques. }\end{array}$ & Alveolar M $\phi$ & $\begin{array}{l}\text {-SVV IE63 proteins are present } \\
\text { in } M \phi \text { in lymph nodes after } \\
\text { SVV reactivation in monkeys. } \\
\text {-SVV infects alveolar } M \phi \text { and } \\
\text { transmit virus to T cells. }\end{array}$ & $\begin{array}{l}\text { SVV-infected M } \phi \text { s were CD163+ } \\
\text { (immunofluorescence analysis) after } \\
\text { virus reactivation but not during } \\
\text { latency. }\end{array}$ & {$[70,71]$} \\
\hline 29 & Frog virus $3(\mathrm{FV} 3)$ & Iridoviridae & dsDNA & $\begin{array}{l}\text { Amphibian } \\
\text { species }\end{array}$ & $\begin{array}{l}\text { Acute systemic } \\
\text { FV3 infection }\end{array}$ & Xenopus laevis & Peritoneal $\mathrm{M} \phi$ & $\begin{array}{l}\text { FV3 persist in peritoneal } \mathrm{M} \phi \\
\text { in vitro. }\end{array}$ & No cytopathic effect on infected $\mathrm{M} \phi$. & [25] \\
\hline
\end{tabular}




\section{Viral Entry into Monocytes and Macrophages}

The initial step of infection is virus contact with the host cell and introduction of its material into the cell. The viral capsid is usually neutrally charged and viruses and cells do not naturally attract each other; therefore, the virus must find a way to move near to a host cell. Most viruses do this by attachment to a susceptible cell that contains a receptor. Initial virus-cell interaction can occur through low- or high-affinity receptors, leading to the activation of many signalling pathways, which in turn can provide virus escape from immune reaction, prevent host cell apoptosis or adapt the cell to the permissiveness. After initial contact with the cell surface, viruses can penetrate into the cell through endocytosis, phagocytosis, macropinocytosis or membrane fusion. It can be assumed that the uptake pathway and type of receptors involved are the first adaptation step necessary to the prosperous survival of viruses.

Endocytosis is a form of a clathrin-mediated molecule transportation. As described in detail by Grove J. and Marsh M. (2011) [72], the receptor-mediated interaction can be represented as follows: receptors can target viruses for endocytosis; receptors may be used to activate specific signalling pathways leading to virus entry; receptors may directly drive fusion/penetration events, either at the surface of a target cell or within endocytic compartments, that can be achieved by inducing conformational changes in key virus surface structures. Phagocytosis is a type of endocytosis that involves the actin-dependent formation of vesicles. Macropinocytosis is an endocytic process of nonselective uptake of extracellular fluid, which can be induced upon activation of growth factor signalling pathways and can also be exploited by several viruses [73]. Virus surface components and the composition of viral coats determine virus-cell interactions and orchestrate their attachment to the cell surface. For example, enveloped viruses, which are packed in a membrane highly similar to that of the host cell, can fuse directly at the plasma membrane after interaction with cell surface receptors [72], as has been shown for HIV-1 [55]. The various mechanisms given here are widely exploited by viruses against many cell populations, in addition to monocyte/macrophage cells.

Monocytes/macrophages are known to be a professional antigen-presenting cells and "professional" phagocytes. These cells are well equipped with general receptors and several sensors, namely, pattern recognition receptors. These receptors can initiate and control immune responses to invading pathogens and maintain tolerance to self-antigens [74]. Data representing virus-cell binding events for viruses that cause lethal or clinically severe diseases are summarized in Table 2 . Receptors and proteins involved in virus-host interactions define the next steps of the viral life cycle. For receptor-mediated entry, viruses can employ both nonspecific receptors, where a virus accesses a broad range of cell populations, or highly specific interactions between the virus and cell surface receptors, where a virus infects a limited set of target cells; this determines the tropism of viral infection. Several viruses use classical receptors and transmembrane proteins that are widely represented in cells and are not restricted to the monocyte/macrophage population, such as nucleolin by the respiratory syncytial virus [75]; sialic acid sugars by the influenza virus [76], mouse hepatitis virus [77] and Theiler's murine encephalomyelitis virus [78]; and phosphatidylserine by the vesicular stomatitis virus [79]. This strategy provides effective interactions with the cell and allows viruses to infect a wide range of cells. Despite the low-affinity of these interactions, further cellular reactions and cascade activation could provide an advantage to viruses in survival. For example, in chronic lymphocytic leukaemia, the nucleolin activation in cells result in stabilization of Bcl-2 mRNA, with subsequent overproduction of Bcl-2 protein and avoidance of apoptosis [80]. Sialic acids are highly conserved and abundant in large numbers in virtually all cells, which makes them a good target for viruses. RSV uses the hemagglutinin glycoproteins on their surface to directly bind to the sialic acids of erythrocytes as a first step of virus interaction with the host that helps to avoid immune response and enables spreading within the organism. Several viruses (HIV, CMV, RSV, KHSV) use heparan sulphate proteoglycans, which have been considered to be a nonspecific cell surface receptor based on their interactions with the positive motifs of viral proteins $[11,81,82]$. However, heparan sulphate proteoglycans play multiple roles in assisting viral infection. It has been suggested that heparan 
sulphate could serve as a specific receptor for viral infection [83]. Heparan sulphate shows activity in assisting both viral binding and viral entry. In the case of HIV infection, these receptors facilitate the internalization of viral trans activator protein, Tat and increase the levels of cytokines, promoting cell proliferation to increase the incidence of cancer and neurotoxicity in the central nervous system. The Tat protein might spread into the uninfected cells to cause the non-permissive cells to be susceptible to HIV infection [83]. Phosphatidylserine plays a valuable role in cell cycle signalling, specifically in relationship to apoptosis. In the viral membrane, phosphatidylserine mimics the membrane fragments generated during cellular apoptosis, which leads to macrophage recognition and internalization by macropinocytosis [73], which then leads to its infection and enables immune escape. 
Table 2. Virus-host cell interactions.

\begin{tabular}{|c|c|c|c|c|c|}
\hline & Virus & Entry Type & Receptor(s) Used for Viral Entry/Attachment & Virus Fate & Reference \\
\hline 1 & Respiratory syncytial virus & $\begin{array}{l}\text { Macropinosome } \\
\text { formation }\end{array}$ & Nucleolin, heparan sulphate proteoglycans & Replication & {$[75,81]$} \\
\hline 2 & Influenza virus & Endocytosis, Phagocytosis & Sialic acid sugars & Replication & [76] \\
\hline 3 & Vesicular stomatitis virus & endocytosis & Phosphatidylserine & No replication & {$[32,79]$} \\
\hline 4 & Mouse hepatitis virus & Phagocytosis & $\begin{array}{l}* \text { Sialic acid sugars and glycolipids } \\
\mathrm{N}-* \text { acetilneuraminic acid receptor }\end{array}$ & No replication & {$[34,77]$} \\
\hline 5 & $\begin{array}{l}\text { Japanese encephalitis virus, } \\
\text { West Nile virus, Dengue virus }\end{array}$ & Phagocytosis & $\begin{array}{c}{ }^{*} \text { DC-SIGN or * DC-SIGNR } \\
\text { TLR-2, TLR-3 and TLR-7, RIG-I }\end{array}$ & Replication & {$[39,40]$} \\
\hline 6 & Coxsackieviruses & Macropinocytosis & ${ }^{*} \mathrm{CAR}$ and IgG Fc fraction receptors (Fc $\gamma \mathrm{RII}$ and Fc $\left.\gamma \mathrm{RIII}\right)$, occludin & Replication & {$[42,73,84]$} \\
\hline 7 & $\begin{array}{c}\text { Theiler's murine } \\
\text { encephalomyelitis virus }\end{array}$ & Endocytosis & Sialic acid sugars & Replication & {$[46,78]$} \\
\hline 8 & $\begin{array}{l}\text { Human immunodeficiency } \\
\text { virus, Simian } \\
\text { immunodeficiency virus }\end{array}$ & $\begin{array}{l}\text { Endocytosis, } \\
\text { macropinocytosis }\end{array}$ & $\begin{array}{c}\text { Human mannose receptor C-type } 1 \\
{ }^{*} \mathrm{CD} 4 \text { and } \mathrm{a} * \text { coreceptors CXCR4 or CCR5, heparan sulphate } \\
\text { proteoglycans }\end{array}$ & Replication & {$[11,85,86]$} \\
\hline 9 & Cytomegalovirus & Endocytosis & $\begin{array}{l}\text { Heparin sulphate proteoglycans following by the binding to the } \beta 1 \\
\text { and } \beta 3 \text { integrins, EGFR, TLR2, TLR3 and TLR9 (murine CMV) }\end{array}$ & Replication & {$[17,82]$} \\
\hline 11 & Human herpesvirus 6 & Endocytosis & *CD46 & $\begin{array}{l}\text { Non-productive } \\
\text { infection }\end{array}$ & {$[63,87]$} \\
\hline 12 & $\begin{array}{l}\text { Kaposi's sarcoma-associated } \\
\text { herpesvirus }\end{array}$ & $\begin{array}{l}\text { * Macropinosome } \\
\text { membrane fusion }\end{array}$ & $\begin{array}{l}\text { xCT, DC-SIGN, * surface heparan sulphate, }{ }^{*} \text { integrin } \alpha 3 \beta 1 \\
(\text { CD49c/29)? }\end{array}$ & Replication & [66-88] \\
\hline 13 & $\begin{array}{l}\text { Varicella-zoster virus, Simian } \\
\text { varicella virus }\end{array}$ & $\begin{array}{l}\text { Fusion with the plasma } \\
\text { membrane or endocytosis }\end{array}$ & * Mannose-6-phosphate receptor, myelin-associated glycoprotein & not clear & {$[71,89]$} \\
\hline
\end{tabular}

* Data nonspecific for $\mathrm{Mo} / \mathrm{M} \phi$. 
Other viruses bind to specific cofactors: Fc $\gamma$ RII and Fc $\gamma$ RIII and occludin for coxsackieviruses [42,73]; CD4 and coreceptors CXCR4/CCR5 or human mannose receptor C-type 1 (hMRC1) for human immunodeficiency virus [11,86]; and $\beta 1 / \beta 3$ integrins and TLR3/TLR9 for cytomegalovirus [82]. Redundancy and conservation of receptors determines viral tropism, spread and pathogenesis of disease [90]. Binding to Fc $\gamma$ RII and Fc $\gamma$ RIII receptors, coxsackievirus launches signalling pathways resulting in the induction of both tumour necrosis factor- $\alpha$ and interleukin- $1 \alpha$ production by human macrophages [91], which are involved in inflammation onset Occludin plays an important role in coxsackievirus B (CVB) entry by launching macropinocytosis and occludin also plays a role in avoidance of immune surveillance [73]. Occludin may serve as a scaffold to recruit and anchor signalling or regulatory molecules, such as a caveolin, in the vicinity of virus entry providing a base for virus entry by endocytosis [92]. CD4 plays a prominent role in HIV entry and virus-cell interaction for T cells and for monocytes/macrophages. CD4 creates structural changes in viral proteins that allow HIV-1 to bind to a coreceptor expressed on the host cell, followed by insertion of a fusion peptide into the host cell and fusing with the membrane [55]. In turn, hMRC1-mediated uptake of HIV-1 by macrophages does not lead to productive infection in macrophages [86] but it facilitates virus transmission to $T$ cells, which is important for virus dissemination and infection establishment This indicates that HIV-1 can also use the interaction with hMRC1 to its advantage [93]. Virus-induced receptor-mediated signalling can cause local actin rearrangement and facilitate phagocytosis, as was shown for cytomegalovirus [72]. HCMV binds to specific proteinaceous receptors-the $\beta 1$ and $\beta 3$ integrins-and to EGFR on the surface of monocytes, then triggers the activation of downstream signalling cascades [17]. The activation of both EGFR and integrins by HCMV is required for increased monocyte cellular motility through actin cytoskeletal rearrangement [17]. Actin rearrangement correlates with the translocation of viral capsids to the nucleus and infection, which is essential for the overall dissemination strategy of HCMV [94]. Numerous viruses can activate cells through different TLRs, including members of Herpesviridae (CMV, EBV) [82]. TLRs participate in the first line of defence against pathogens. They play a significant role in inflammation, immune cell regulation, survival and proliferation [95]. Although activation of TLRs might result in a protective antiviral immune response, it also may contribute to the pathology observed in infections caused by EBV [82]. Sensing of EBV by TLR2 results in increased secretion of proinflammatory cytokines, such as TNF- $\alpha$, IL-1 $\beta$, IL-6 and IL-8, which in turn contribute to the pathology observed in infections caused by EBV [82]. DC-SIGN and other C-type lectins act as pathogen recognition receptors that alert macrophages to take up and process pathogens for antigen presentation to T cells. Certain viruses such as HHV-8 can subvert this immune function by using DC-SIGN as a portal for immune dysfunction, resulting in the oncogenesis caused by HHV-8 infection [66]. Another example is the upregulation of $\mathrm{xCT}$, which serves as a fusion-entry receptor for HHV-8 in infected macrophages; this receptor protects these cells from reactive nitrogen species-induced cell death [67].

In addition to the classic entry scenario that uses cell surface receptors and subsequent endocytosis, macropinocytosis, or membrane fusion for cell entry, some viruses infect macrophages through phagocytosis of apoptotic macrophages that were previously infected by that virus [96].

\section{Productive Viral Infection}

The fate of viruses and the cells affected by viral agents varies greatly depending upon the virus characteristics, although the fate can be grouped into 3 categories as follows: (1) persistence with productive viral replication; (2) persistence with a very limited time/amount of replication, or partial replication; and (3) restricted or short-term persistence with no/undetectable replication (cell here considered as a "random victim"). Monocytes/macrophages are the first subpopulation of immune cells that contact pathogens and can be infected and serve as a vehicle for virus dissemination; they are less likely to serve as a reservoir due to their naturally short life span and inability to support viral gene expression and replication [17]. Infected monocytes cross the blood-tissue barrier and disseminate viral particles as a specific parcels into the central nervous system, playing the role of the "Trojan horse," which is common in HIV [1,2,11], HCV [38], HCMV [17] and Japanese encephalitis 
virus (JEV) [97]. Viruses need to overcome a number of hurdles to be able to successfully infect and replicate in monocyte/macrophage cells. According to an inner genetic program, after three days of circulation in blood vessels, monocytes must make a cell fate decision-either differentiate into tissue macrophages or default to biological programming and undergo apoptosis [17]. Here, viruses demonstrate their superb ability to modulate and navigate cells in order to escape degradation and replicate effectively in an organism. They evade apoptosis and prolong the cell's life span via regulation of specific apoptotic pathways (PI3K and NFkB), that involves microRNAs $[67,98]$ and modulation of the mitochondrial pathway [99]. They provoke changes in cell polarization, hide viral receptors from the cell surface and alter chemokine/cytokine expression in order to evade the immune response; they also affect cell motility to promote viral spread and dissemination in the body. Relevant data concerning viral persistence, cell responses and replication are summarized in Table 1 and are graphically presented in Figure 1 Several examples have confirmed these findings in detail.

An accumulation of evidence suggests that macrophages are not only random targets for HIV, they are also important and specialized viral reservoirs distributed throughout the body that store large amounts of unintegrated viral DNA in circular form in internal compartments [18]. HIV-1 infected macrophages were found in several body locations such as spleen, lung, heart, colon, brain and adipose tissue; this represents a major challenge for cure efforts due to the low drug delivery efficiency into these tissues $[100,101]$. Although CD4+ T cells are considered to be major permissive cells for HIV-1, the size of the virus reservoir is small. Approximately 1 infectious unit per million resting CD4+ T cells (1 IUPM) harbour the replication-competent proviral HIV-1 DNA [102]. Macrophages can also sustain a linear, steady amount of HIV-1 production, releasing replication-competent viral particles [103]. Attempts to assess the size of a viral reservoir in macrophages was recently carried out by Avalos C. R. et al. (2017) [100]. The authors applied a novel quantitative viral outgrowth assay in SIV-infected macaques that were ART-treated for 500 days and they revealed several interesting facts. First, even after antiretroviral therapy, $87 \%$ of suppressed animals contained latently infected brain macrophages, which were able to produce replication competent SIV. Second, unlike CD4+ T cells, the number of productively infected macrophages varied greatly across different tissues from the same macaque; this could be important for infection establishment and treatment strategy. Third, the highest levels of SIV production were found in spleen and brain macrophages (both microglial and perivascular) and was higher than the level of SIV production in CD4+ T cells, although these parameters could not be directly compared [100,104].

Macrophages are appealing to HIV-1 infection in many ways. They support productive replication and a life-long persistence as a latent reservoir that is provided by the cell machinery changes. HIV- 1 adjusts macrophage for their existence by abolishing apoptosis and affecting several pathways that allow the virus to extend the period of persistence. HIV- 1 infection of macrophages leads to overexpression of the Nef viral protein, which interacts with apoptosis signal regulating kinase-1. This result in the inhibition of Fas- and TNF receptor-mediated apoptosis and immune escape by preventing recognition by cytotoxic $\mathrm{T}$ lymphocytes $[55,105,106]$. Resistance to apoptosis also involves direct modulation of the mitochondrial pathway by regulating Bax pore induction [99]. Upon HIV-1 infection, macrophages increase their telomerase activity [107] and activate the expression of colony stimulating factor (M-CSF) protein [108]. After infection, macrophages actively secrete proinflammatory cytokines and chemokines that attract permissive cells within their vicinity, thereby transmitting virus to uninfected T cells, playing a crucial role in transmission and dissemination of HIV to other organs, including the brain [18]. The acute phase of HIV infection is characterized by a predominance of M1 macrophages expressing Th1 cytokines and chemokines (IFN- $\gamma$, IL-2, IL-12 and CCL3, CCL4, CCL5, respectively) and proinflammatory cytokines (TNF- $\alpha$, IL-1 $\beta$, IL-6 and IL-18). This inflammatory phenotype is characterized by a poor surface expression of CD4 and DC-SIGN, which are important receptors for HIV-1 binding [104]. The low abundance of specific receptors prevents superinfection in infected macrophages without restriction of viral replication [11]. However, at later stages of viral infection, there is a shift of macrophages to M2 due to the presence of IL-4 and 
IL-13, which favours the progression to AIDS [11]. Along with the above mentioned impairments, infected macrophages show phagocytosis impairments of apoptotic neutrophils during HIV infection, where the Nef protein plays a crucial role. The persistence of apoptotic neutrophils and their apoptotic bodies at the inflammatory site may maintain the inflammatory state through persistent stimulation of proinflammatory cytokines (TGF $\beta-1$, prostaglandin E2 and platelet-activating factor) $[109,110]$. Macrophages also show anti-HIV-1 cellular restrictions such as the expression of SAMHD1, APOBEC $3 A$, APOBEC3G, tetherin, TRIM5-alpha and MX2 [17], suggesting the substantial importance of macrophages in HIV-1 pathogenesis. Monocyte differentiation into polarized macrophages and their dissemination into tissues are critical for the establishment of HIV-1 infection. First, resident tissue macrophages remain in tissues long term, with a capability of self-renewal upon cell machinery changes; second, macrophages are relatively resistant to the cytopathic effects of HIV infection compared to CD4+ T cells. Together, these peculiar qualities provide a basis for the formation of a stable viral reservoir, which is recognized as a major barrier to curing HIV-1 infections [104].

There is a wide range of disease pathologies seen in several organ sites associated with human cytomegalovirus infection. HCMV is involved in chronic inflammation and the development of cardiovascular diseases and some types of cancers in immunocompetent individuals $[111,112]$. HCMV has the potential to contribute to tumour progression by oncomodulation through the production of viral proteins, affecting cellular differentiation, gene expression, DNA replication and cell cycle progression [113]. The virus leads to immunosuppression, which may further lead to immunotolerance against the growing tumour [113]. HCMV-induced pathologies are mediated predominately by infected monocytes, which serves as a permissive system and are a long-term reservoir for the virus. Productive virus release of HCMV from monocytes/macrophages is detectable up to 16 weeks after infection [17]. This virus overcomes a number of biological hurdles in the monocytes to provide support for viral gene expression and replication. Monocytes become permissive only upon their differentiation into macrophages, which is driven by the virus, resulting in progeny virions capable of infecting the necessary surrounding cell types. Monocyte-to-macrophage differentiation is partially mediated by caspase-3 activation [17]. It was shown that HCMV could specifically regulate the polarization of infected monocytes/macrophages to achieve an effective balance between proinflammatory and anti-inflammatory signals. This regulation may establish a cellular environment that is conducive for the dissemination and persistence of HCMV (the "Goldilocks" phenomenon) [17]. During latency, HCMV modulates cytokine/chemokine secretion for the biased recruitment of immune cells to propagate latency in the host. Stevenson E. et al. (2014) [17] hypothesized a very specific role of HCMV in monocyte/macrophages modulation. According to this hypothesis, viruses promote a "finely-tuned" cell type, where monocytes/macrophages exist somewhere along the M1/M2 continuum that is needed for viral spread, replication and persistence. HCMV drives the simultaneous expression of M1- (IL-6, TNF- $\alpha$, CD86) and M2-associated molecules (IL-10 and CD163). HCMV likely employs M1-associated markers and chemokines to promote the proinflammatory activation of infected monocytes/macrophages. This ensures elevated cellular motility, migration and monocyte recruitment, which has also been observed for infected tumour cells [113]. At the same time, HCMV use M2-associated macrophage markers and chemokines to silence the tissue-damaging effects of the pro-inflammatory response and any potential anti-viral responses [17]. HCMV belongs to the agents capable of long-lasting infection due to cell apoptosis decoy. Thus, after infection, cytomegalovirus induces activation of EGFR and the $\beta 1$ and $\beta 3$ integrins on the surface of monocytes, leading to the prolonged survival of infected cells by the prolonged expression of $\mathrm{Mcl}-1$ [98,114].

The long persistence in liver macrophages was observed for a member of Flaviviridae family-the hepatitis $C$ virus, albeit in small quantities. It was detected in cells up to 9 years after therapy [37]. Chronic HCV infection can lead to advanced liver fibrosis, cirrhosis and hepatocellular carcinoma and constitutes a significant health burden worldwide [115]. Despite the tropism to hepatocytes, monocytes/macrophages also play an important role in HCV replication in vivo, showing productive replication of a virus in a relatively nonspecific manner as long as macrophages survive [116]. 
Flaviviruses successfully replicate their genome and can evade and/or subvert the macrophage response to favour survival and replication due to elevated TNF expression, along with the increased expression of NOS2 and the antiviral (but immune-suppressive) enzyme indolamine-2-3 dioxygenase production [40]. In addition to hepatocytes, microglial cells of HCV-infected individuals have been shown to be virus-positive, demonstrating significantly higher levels of proinflammatory cytokines IL-1a, IL-1b, TNFa, IL-12 and IL-18 and increased transcription of chemokines IL-8, IL-16 and IP-10 [38]. Some authors speculate that the release of proinflammatory cytokines and neurotoxins such as NO and HCV viral proteins upon infection could potentially induce changes in brain function, leading to neurocognitive dysfunction and depression [38].

Members of Togaviridae, the Chikungunya alphavirus and the Ross River virus, have been shown to persist in macrophages for a long time. CHIKV persist in synovial tissue after 18 months in patient after infection [50], with the productive replication of virus in synovial macrophages [20]. The Ross River virus showed high level of replication in macrophages shortly after infection but viral antigens were also detectable by IFA analysis after 170 days in an in vitro model, indicating that the virus had not been completely cleared from the cells [52]. Despite the induced apoptosis in many cell types, CHIKV appears to launch a specific innate immune response in infected cells through the increased levels of $\mathrm{TNF} \alpha$, controlled by NFkB activation [49]. Moreover, this virus utilizes a high cell mortality for its dissemination into apoptotic blebs [20].

There are several examples of persistence that are very limited in the time or amount replication. It is known that lytic productive replication leads to high mortality of permissive cells but not in the case of macrophages. For example, macrophages carrying virus particles can survive due to the limited replication of virus, as was demonstrated for Frog virus 3 [25]. This phenomenon provides additional time for the dissemination in organism and to infect other cell populations in the vicinity. Among the viruses with short replication times in macrophages are the Theiler's murine encephalomyelitis virus (TMEV) and the respiratory syncytial virus (RSV). Experiments in vitro using different cell lines have demonstrated the upregulation of IL-10 and the downregulation of IFN- $\alpha$, INF- $\beta$ and IFN-g, which may contribute to the TMEV persistence. Upregulation of these mediators, as well as B-lymphocyte chemoattractant (BLC) and granulocyte colony-stimulating factor (G-CSF), were observed in macrophages after infection and may contribute to the acceleration of TMEV-induced demyelination resembling multiple sclerosis [46]. Information regarding cell machinery modifications upon TMEV infection is contradictory. There are alterations in the immune response of those cells that contribute to chronic inflammatory responses from macrophages and changes that allow infected macrophages to escape from immune response $[117,118]$. Productive RSV infection was found in isolated human alveolar macrophages in vitro for at least 25 days, suggesting that macrophages may be important targets for RSV during acute infection [26]. RSV-infected cells showed lack of autocrine response to the constitutively produced IFN- $\beta$ by inhibition of STAT1 phosphorylation. This may prevent the transcription of antiviral genes and consequently allow the maintenance of persistent RSV infection [27].In addition to a group of viruses that can replicate their genome and produce infectious particles in monocyte/macrophage cells, there are a set that carry out a latent infection, exploiting cells only as a potential reservoir for viral storage.

\section{Latent Viral Infection and Inflammation}

Some infection agents use macrophages to establish a latent infection. Viral latency characterized by the ability of a pathogenic virus to lie dormant within infected cells. It is a state of reversibly non-productive infection of cells and provides an important mechanism for viral persistence and escape from immune recognition and drug pressure [104]. It could contribute to several pathologies by promoting chronic inflammation and a subsequent predisposition to cognitive impairments, inflammatory demyelinating disease and multiple sclerosis, precancerous lesions and cancer [12]. Human herpesvirus 8 (HHV-8) infection correlates with an elevated risk of prostate cancer development. HHV-8 was shown to establish a chronic latent infection in epithelial cells 
and macrophages, which contributed to increased macrophage infiltration in tissue that serve as a cofactor for prostate cancer development in Tobagonian males [68]. Other viruses, such as retroviruses, flaviviruses, alphaviruses, picornaviruses and rhabdoviruses, are commonly associated with skeletal muscle infection and inflammation, leading to either direct infection of myofibers or infiltrating inflammatory macrophages [48]. Although macrophages are not the major reservoirs of varicella zoster virus $(\mathrm{VZV})$, infection causes an intense inflammatory response during the reactivation of VZV, leading to widespread necrosis of glial cells and neurons [70]. Clinically, herpes zoster is associated with severe, acute pain and frequently, prolonged severe pain or post herpetic neuralgia. It often requires follow-up medical care for months or even years after the initial attack [70].

A member of the Flaviviridae family, Zika virus, was identified in 1947 but initially garnered little interest from scientists. Today, it attracts much attention within the scientific community given the recent evidence of linkages to microcephaly in new-borns, central nervous system abnormalities, foetal growth restriction, maternal Guillain-Barré symptoms and its rapid spread around the globe [3]. Human placental macrophages, called Hofbauer cells, play a prominent role in virus dissemination. Zika virus replicates in macrophages for at least 96 hours after infection in vitro, which lead to little induction of pro-inflammatory cytokines and chemokines and antiviral gene expression, with minimal cell death [41]. It results in a weaker immune response that prolongs the virus infection and persistence in body tissues [119] Infected macrophages showed strong activation of migration inhibitory factor (MIF), which leads to a higher migration ability of infected cells and can boost virus ability to cross the placental barrier and promote its spread in the body [119].

Several types of viruses utilize macrophages as a potential reservoir for viral storage in the absence of replication, as was demonstrated for vesicular stomatitis virus [32]. It was shown that macrophages are the major target cells of Maedi-visna virus despite very limited replication in the animal host [57]. HHV-6 infection is typically non-productive in macrophages; nevertheless, it induces severe functional abnormalities, including the selective suppression of IL-12, a critical cytokine in the generation of M1-polarized antiviral immune responses [63]. An additional mechanism of cell transformation utilized by HHV-6 is immunomodulation, which includes alterations in the cell surface receptor expression that can facilitate its own spread and persistence [63].

Therefore, it has to be assumed that viruses manipulate the cell biology of monocytes/macrophages in order to utilize them as a repository for dissemination, to promote long-term persistence within infected tissues and for enabling virus replication under favourable conditions.

\section{Macrophages as a Target for Therapeutic Intervention}

Monocytes/macrophages play a critical role in several virus-mediated diseases and represent a major hurdle for treatment. Therapeutic targeting of macrophages is challenging, as these cells reside broadly dispersed in nearly all tissues, including those that are difficult to access with drugs such as the CNS and adipose tissue. Nevertheless, several attempts have been undertaken.HIV-1 persists in CD4+ T cells and macrophages and cannot be eliminated by antiretroviral therapy [106]. There are several therapeutic agents available on market; however, for macrophages, protease inhibitors (PIs) are currently the only approved drugs. One of the hurdles to clinical implementation is the pharmacokinetics of a drug. When targeting macrophages, approximately 15- to 89-fold higher concentrations of PIs are required compared with CD4+ T cells [120]. Despite the failure of macrophage-HIV eradication, another innovative idea has been successfully implemented. Liao H.K. et al. (2015) [121] showed a significant reduction of HIV-1 expression by using a multiplexed CRISPR/Cas9 system. The result was also confirmed in primary CD4+ T cells [122].

When activated by HCV, macrophages play a critical role in hepatic inflammation and fibrosis progression [123]. The approved direct-acting antiviral (DAA) therapy for HCV patients aims for viral clearance, mainly in hepatocytes. However, recent data show a positive effect of the treatment on myeloid cells. A sustained virological response, as assessed by the kinetics of soluble CD163 in the serum of patients, was achieved for the clearance of the HCV virus, with consequent mitigation of 
inflammation, confirming the relevance of monocyte/macrophage populations in HCV-mediated liver pathologies [123]. JEV and West Nile virus are the leading cause of acute viral meningoencephalitis worldwide [124]. Recently, a pharmacologic method of microglia depletion (PLX5622, Plexxikon Inc., Berkeley, CA, USA, an inhibitor of colony-stimulating factor 1 receptor) has been applied experimentally to evaluate macrophage involvement in viral clearance and CNS injury as part of the neuroinflammatory process [125]. It is known that microglial cells are a significant target for the Japanese encephalitis virus [125]. Seitz S. et al. (2018) [125] showed that PLX5622 treatment lead to a dramatically increased disease severity and increased virus titres and mortality following Flavivirus infection. The authors speculate that microglia could have an additional protective function that is critical in controlling viral infection [125]. These data demonstrate the crucial role of macrophages in virus establishment and clearance and should be taken into consideration when targeting macrophages in therapeutic interventions. Apart from antiviral therapy, nonsteroidal anti-inflammatory drugs are used for virus-induced pathologies; this has been applied for the Ross River virus and other viral arthritides [126]. RRV causes arthralgia and/or arthritis, with many patients experiencing myalgia and fatigue and some experiencing fever and rash [127]. Macrophages are central players in the onset of viral arthropathies, expressing a spectrum of cytokines and chemokines upon infection. Rulli N.E. et al. (2009) [126] demonstrated that bindarit-based treatment (an inhibitor of chemokine synthesis) reduced macrophage infiltration into the muscles and joints, which led to reduced TNF $\alpha$ and NOS2 expression; this resulted in reduced tissue damage and a significant amelioration of disease symptoms.

\section{Conclusions}

Accumulating evidence demonstrates that despite being a suboptimal replication system, monocytes/macrophages cannot escape viral attack. Pathogens attack a variety of cells and utilize diverse bypass mechanisms to enter, change cell machinery and impact the fate of cellular decisions in favour of their replication and propagation.

Several questions remain unclear and have potential for future investigations. What is the longevity of infected macrophages in tissues? How big are the size of macrophage reservoirs in tissues upon different infections and what impacts on disease progression and therapy could this have? The role of the microbiome in infection and its changes upon viral infection has attracted increasing scientific attention. Although this field is unexplored for the majority of viruses, pilot data has obtained, for example, for HIV-1 and HCV infections [128-132]. Several publications have described a decrease of gut microbial alpha-diversity, that inversely correlates with monocyte activation upon microbial translocation in HIV-1-infected patients compared to healthy controls [128,131]; gut dysbiosis, accompanied by systemic inflammation and endotoxemia in HCV-infected individuals [129]. But how do infected macrophages interact with the microbiota to influence disease onset and progression? This information could guide further development of effective therapies, with the aim to reduce microbial translocation and misbalance, diminish subsequent immune activation and reduce morbidity and mortality in virus-driven diseases. These small populations of infected monocytes/macrophages have the potential to be milestones in the understanding of virus-induced diseases and their complications, playing a crucial role in inflammation and possibly in systemic pathology.

Author Contributions: E.N. and J.K. were involved in the conception, literature review and drafting the manuscript; J.K., I.L., and E.C. critically revised the manuscript for important intellectual content; E.N., J.K., and E.C. conceptualized the review, supervised all aspects of the study, and critically reviewed and revised the manuscript. All authors approved the final manuscript as submitted. All authors read and approved the final manuscript.

Funding: This research was funded by ORYX Alpha, Munich, by the ERA Net RUS Plus S\&T CHIT-ALPHA-THER grant, the Russian Foundation for Basic Research (project number 16-54-76015), and by the Tomsk State University Competitiveness Improvement Program (project number 8.1.23.2018).

Acknowledgments: We are grateful to Harald zur Hausen for his interest, discussions and suggestions regarding the manuscript.

Conflicts of Interest: The authors declare no conflicts of interest. 


\section{Abbreviations}

$\begin{array}{ll}\text { Mo } & \text { Monocyte } \\ \text { M } \phi & \text { Macrophage } \\ \text { MDM } & \text { Monocyte-derived macrophages } \\ \text { HC } & \text { Hofbauer cells } \\ \text { HIV } & \text { Human immunodeficiency virus } \\ \text { HCMV } & \text { Human cytomegalovirus } \\ \text { RSV } & \text { Respiratory syncytial virus } \\ \text { VSV } & \text { Vesicular stomatitis virus } \\ \text { dsDNA } & \text { Double stranded DNA } \\ \text { ssRNA } & \text { Single stranded RNA } \\ \text { CSFV } & \text { Classical swine fever virus } \\ \text { EMCV } & \text { Encephalomyocarditis virus } \\ \text { MHV } & \text { Mouse hepatitis virus } \\ \text { ZIKV } & \text { Zika virus } \\ \text { MVV } & \text { Maedi-visna virus } \\ \text { EBV } & \text { Epstein-Barr virus } \\ \text { KSHV } & \text { Kaposi's sarcoma-associated herpesvirus } \\ \text { HHV-6 } & \text { Human herpesvirus 6 } \\ \text { VZV } & \text { Simian varicella-zoster virus } \\ \text { JEV } & \text { Japanese encephalitis virus } \\ \text { AIDS } & \text { Acquired immune deficiency syndrome } \\ \text { CHIKV } & \text { Chikungunya alphavirus } \\ \text { TMEV } & \text { Theiler's murine encephalomyelitis virus }\end{array}$

\section{References}

1. Liu, Y.; Tang, X.P.; McArthur, J.C.; Scott, J.; Gartner, S. Analysis of human immunodežciency virus type 1 evidence for monocyte trafžcking into brain. J. Neurovirol. 2000, 6, S70-S81. [PubMed]

2. Fischer-Smith, T.; Rappaport, J. Evolving paradigms in the pathogenesis of hiv-1-associated dementia. Expert Rev. Mol. Med. 2005, 7, 1-26. [CrossRef] [PubMed]

3. Boeuf, P.; Drummer, H.E.; Richards, J.S.; Scoullar, M.J.; Beeson, J.G. The global threat of zika virus to pregnancy: Epidemiology, clinical perspectives, mechanisms, and impact. BMC Med. 2016, 14, 112. [CrossRef] [PubMed]

4. Tauber, A.I. Metchnikoff and the phagocytosis theory. Nat. Rev. Mol. Cell Boil. 2003, 4, 897-901. [CrossRef] [PubMed]

5. Okabe, Y.; Medzhitov, R. Tissue biology perspective on macrophages. Nat. Immunol. 2016, 17, 9-17. [CrossRef] [PubMed]

6. Gordon, S.; Plüddemann, A.; Martinez Estrada, F. Macrophage heterogeneity in tissues: Phenotypic diversity and functions. Immunol. Rev. 2014, 262, 36-55. [CrossRef] [PubMed]

7. Epelman, S.; Lavine, K.J.; Randolph, G.J. Origin and functions of tissue macrophages. Immunity 2014, 41, 21-35. [CrossRef] [PubMed]

8. Sintiprungrat, K.; Singhto, N.; Sinchaikul, S.; Chen, S.-T.; Thongboonkerd, V. Alterations in cellular proteome and secretome upon differentiation from monocyte to macrophage by treatment with phorbol myristate acetate: Insights into biological processes. J. Proteom. 2010, 73, 602-618. [CrossRef] [PubMed]

9. Kzhyshkowska, J.; Gudima, A.; Moganti, K.; Gratchev, A.; Orekhov, A. Perspectives for monocyte/macrophage-based diagnostics of chronic inflammation. Transfus. Med. Hemother. 2016, 43, 66-77. [CrossRef] [PubMed]

10. Atri, C.; Guerfali, F.Z.; Laouini, D. Role of human macrophage polarization in inflammation during infectious diseases. Int. J. Mol. Sci. 2018, 19, 1801. [CrossRef] [PubMed]

11. Herbein, G.; Varin, A. The macrophage in hiv-1 infection: From activation to deactivation? Retrovirology 2010, 7, 33. [CrossRef] [PubMed] 
12. Murakami, M. The Molecular Mechanisms of Chronic Inflammation Development; Frontiers E-books: Lausanne, Switzerland, 2012; ISBN 2889190919.

13. Wardley, R.; Wilkinson, P. The growth of virulent African swine fever virus in pig monocytes and macrophages. J. Gen. Virol. 1978, 38, 183-186. [CrossRef] [PubMed]

14. Gazzolo, L.; Moscovici, C.; Moscovici, M. Persistence of avian oncoviruses in chicken macrophages. Infect. Immun. 1979, 23, 294-297. [PubMed]

15. Nagra, R.M.; Wong, P.K.; Wiley, C.A. Expression of major histocompatibility complex antigens and serum neutralizing antibody in murine retroviral encephalitis. J. Neuropathol. Exp. Neurol. 1993, 52, 163-173. [CrossRef] [PubMed]

16. Clatch, R.J.; Miller, S.D.; Metzner, R.; Dal Canto, M.C.; Lipton, H.L. Monocytes/macrophages isolated from the mouse central nervous system contain infectious theiler's murine encephalomyelitis virus (TMEV). Virology 1990, 176, 244-254. [CrossRef]

17. Stevenson, E.V.; Collins-McMillen, D.; Kim, J.H.; Cieply, S.J.; Bentz, G.L.; Yurochko, A.D. Hcmv reprogramming of infected monocyte survival and differentiation: A goldilocks phenomenon. Viruses 2014, 6, 782-807. [CrossRef] [PubMed]

18. Abbas, W.; Tariq, M.; Iqbal, M.; Kumar, A.; Herbein, G. Eradication of HIV-1 from the macrophage reservoir: An uncertain goal? Viruses 2015, 7, 1578-1598. [CrossRef] [PubMed]

19. Hoarau, J.-J.; Bandjee, M.-C.J.; Trotot, P.K.; Das, T.; Li-Pat-Yuen, G.; Dassa, B.; Denizot, M.; Guichard, E.; Ribera, A.; Henni, T. Persistent chronic inflammation and infection by chikungunya arthritogenic alphavirus in spite of a robust host immune response. J. Immunol. 2010, 184, 5914-5927. [CrossRef] [PubMed]

20. Jaffar-Bandjee, M.C.; Das, T.; Hoarau, J.J.; Trotot, P.K.; Denizot, M.; Ribera, A.; Roques, P.; Gasque, P. Chikungunya virus takes centre stage in virally induced arthritis: Possible cellular and molecular mechanisms to pathogenesis. Microbes Infect. 2009, 11, 1206-1218. [CrossRef] [PubMed]

21. Ruelas, D.S.; Greene, W.C. An integrated overview of hiv-1 latency. Cell 2013, 155, 519-529. [CrossRef] [PubMed]

22. Kundu, K.; Dutta, K.; Nazmi, A.; Basu, A. Japanese encephalitis virus infection modulates the expression of suppressors of cytokine signaling (SOCS) in macrophages: Implications for the hosts' innate immune response. Cell. Immunol. 2013, 285, 100-110. [CrossRef] [PubMed]

23. Costers, S.; Delputte, P.L.; Nauwynck, H.J. Porcine reproductive and respiratory syndrome virus-infected alveolar macrophages contain no detectable levels of viral proteins in their plasma membrane and are protected against antibody-dependent, complement-mediated cell lysis. J. Gen. Virol. 2006, 87, 2341-2351. [CrossRef] [PubMed]

24. Psalla, D.; Psychas, V.; Spyrou, V.; Billinis, C.; Papaioannou, N.; Vlemmas, I. Pathogenesis of experimental encephalomyocarditis: A histopathological, immunohistochemical and virological study in mice. J. Comp. Pathol. 2006, 135, 142-145. [CrossRef] [PubMed]

25. Robert, J.; Abramowitz, L.; Gantress, J.; Morales, H.D. Xenopus laevis: A possible vector of ranavirus infection? J. Wildl. Dis. 2007, 43, 645-652. [CrossRef] [PubMed]

26. Panuska, J.R.; Cirino, N.M.; Midulla, F.; Despot, J.; McFadden, E., Jr.; Huang, Y. Productive infection of isolated human alveolar macrophages by respiratory syncytial virus. J. Clin. Investig. 1990, 86, 113-119. [CrossRef] [PubMed]

27. Rivera-Toledo, E.; Torres-González, L.; Gómez, B. Respiratory syncytial virus persistence in murine macrophages impairs ifn- $\beta$ response but not synthesis. Viruses 2015, 7, 5361-5374. [CrossRef] [PubMed]

28. Nakamura-Lopez, Y.; Villegas-Sepúlveda, N.; Gómez, B. Rsv p-protein impairs extrinsic apoptosis pathway in a macrophage-like cell line persistently infected with respiratory syncytial virus. Virus Res. 2015, 204, 82-87. [CrossRef] [PubMed]

29. Gladkov, S.; Zinserling, V.; Shtro, A.; Belyaevskaya, S.; Zarubaev, V. postmortem diagnosis of influenza during its epidemic and interepidemic periods. Arkhiv Patol. 2014, 77, 22-27. [CrossRef] [PubMed]

30. Pleskov, V.; Zarubaev, V.; Pleskova, I. reticuloendothelial system and persistence of influenza virus in the body. Vopr. Virusol. 1995, 41, 53-58.

31. Perrone, L.A.; Plowden, J.K.; García-Sastre, A.; Katz, J.M.; Tumpey, T.M. H5n1 and 1918 pandemic influenza virus infection results in early and excessive infiltration of macrophages and neutrophils in the lungs of mice. PLoS Pathog. 2008, 4, e1000115. [CrossRef] [PubMed] 
32. Simon, I.D.; van Rooijen, N.; Rose, J.K. Vesicular stomatitis virus genomic rna persists in vivo in the absence of viral replication. J. Virol. 2010, 84, 3280-3286. [CrossRef] [PubMed]

33. Kipar, A.; Meli, M.L.; Baptiste, K.E.; Bowker, L.J.; Lutz, H. Sites of feline coronavirus persistence in healthy cats. J. Gen. Virol. 2010, 91, 1698-1707. [CrossRef] [PubMed]

34. Cipková-Jarčušková, J.; Chalupkova, A.; Hrabovska, Z.; Wagnerova, M.; Mistrikova, J. Biological and pathogenetic characterization of different isolates of murine gammaherpesvirus 68 (mhv-68) in the context of study of human oncogenic gammaherpesviruses. Acta Virol. 2013, 57, 105-112. [CrossRef] [PubMed]

35. Glass, W.G.; Chen, B.P.; Liu, M.T.; Lane, T.E. Mouse hepatitis virus infection of the central nervous system: Chemokine-mediated regulation of host defense and disease. Viral Immunol. 2002, 15, 261-272. [CrossRef] [PubMed]

36. Lee, W.; Wang, C.; Chien, M. Virus antigen expression and alterations in peripheral blood mononuclear cell subpopulations after classical swine fever virus infection. Vet. Microbiol. 1999, 67, 17-29. [CrossRef]

37. Radkowski, M.; Gallegos-Orozco, J.F.; Jablonska, J.; Colby, T.V.; Walewska-Zielecka, B.; Kubicka, J.; Wilkinson, J.; Adair, D.; Rakela, J.; Laskus, T. Persistence of hepatitis c virus in patients successfully treated for chronic hepatitis c. Hepatology 2005, 41, 106-114. [CrossRef] [PubMed]

38. Wilkinson, J.; Radkowski, M.; Eschbacher, J.M.; Laskus, T. Activation of brain macrophages/microglia cells in hepatitis c infection. Gut 2010, 59, 1394-1400. [CrossRef] [PubMed]

39. Myint, K.S.A.; Kipar, A.; Jarman, R.G.; Gibbons, R.V.; Perng, G.C.; Flanagan, B.; Mongkolsirichaikul, D.; Van Gessel, Y.; Solomon, T. Neuropathogenesis of japanese encephalitis in a primate model. PLoS Negl. Trop. Dis. 2014, 8, e2980. [CrossRef] [PubMed]

40. Ashhurst, T.M.; van Vreden, C.; Munoz-Erazo, L.; Niewold, P.; Watabe, K.; Terry, R.L.; Deffrasnes, C.; Getts, D.R.; King, N.J.C. Antiviral macrophage responses in flavivirus encephalitis. Indian J. Med. Res. 2013, 138, 632-647. [PubMed]

41. Quicke, K.M.; Bowen, J.R.; Johnson, E.L.; McDonald, C.E.; Ma, H.; O’Neal, J.T.; Rajakumar, A.; Wrammert, J.; Rimawi, B.H.; Pulendran, B.; et al. Zika virus infects human placental macrophages. Cell Host Microbe 2016, 20, 83-90. [CrossRef] [PubMed]

42. Alidjinou, E.K.; Sané, F.; Trauet, J.; Copin, M.-C.; Hober, D. Coxsackievirus b4 can infect human peripheral blood-derived macrophages. Viruses 2015, 7, 6067-6079. [CrossRef] [PubMed]

43. Liu, L.; Yue, Y.; Xiong, S. Nk-derived ifn- $\gamma /$ il-4 triggers the sexually disparate polarization of macrophages in crb3-induced myocarditis. J. Mol. Cell. Cardiol. 2014, 76, 15-25. [CrossRef] [PubMed]

44. Ghazarian, L.; Diana, J.; Beaudoin, L.; Larsson, P.G.; Puri, R.K.; Van Rooijen, N.; Flodström-Tullberg, M.; Lehuen, A. Protection against type 1 diabetes upon coxsackievirus b4 infection and inkt-cell stimulation role of suppressive macrophages. Diabetes 2013, 62, 3785-3796. [CrossRef] [PubMed]

45. Shaheen, Z.R.; Corbett, J.A. Macrophage expression of inflammatory genes in response to emcv infection. Biomolecules 2015, 5, 1938-1954. [CrossRef] [PubMed]

46. Himeda, T.; Okuwa, T.; Muraki, Y.; Ohara, Y. Cytokine/chemokine profile in j774 macrophage cells persistently infected with da strain of theiler's murine encephalomyelitis virus (tmev). J. Neurovirol. 2010, 16, 219-229. [CrossRef] [PubMed]

47. Bröer, S.; Käufer, C.; Haist, V.; Li, L.; Gerhauser, I.; Anjum, M.; Bankstahl, M.; Baumgärtner, W.; Löscher, W. Brain inflammation, neurodegeneration and seizure development following picornavirus infection markedly differ among virus and mouse strains and substrains. Exp. Neurol. 2016, 279, 57-74. [CrossRef] [PubMed]

48. Watson, N.B.; Schneider, K.M.; Massa, P.T. Shp-1-dependent macrophage differentiation exacerbates virus-induced myositis. J. Immunol. 2015, 194, 2796-2809. [CrossRef] [PubMed]

49. Kumar, S.; Jaffar-Bandjee, M.-C.; Giry, C.; de Kerillis, L.C.; Merits, A.; Gasque, P.; Hoarau, J.-J. Mouse macrophage innate immune response to chikungunya virus infection. Virol. J. 2012, 9, 313. [CrossRef] [PubMed]

50. Labadie, K.; Larcher, T.; Joubert, C.; Mannioui, A.; Delache, B.; Brochard, P.; Guigand, L.; Dubreil, L.; Lebon, P.; Verrier, B. Chikungunya disease in nonhuman primates involves long-term viral persistence in macrophages. J. Clin. Investig. 2010, 120, 894-906. [CrossRef] [PubMed]

51. Suhrbier, A.; La Linn, M. Clinical and pathologic aspects of arthritis due to ross river virus and other alphaviruses. Curr. Opin. Rheumatol. 2004, 16, 374-379. [CrossRef] [PubMed] 
52. Way, S.J.; Lidbury, B.A.; Banyer, J.L. Persistent ross river virus infection of murine macrophages: An in vitro model for the study of viral relapse and immune modulation during long-term infection. Virology 2002, 301, 281-292. [CrossRef] [PubMed]

53. Assunção-Miranda, I.; Cruz-Oliveira, C.; Da Poian, A.T. Molecular mechanisms involved in the pathogenesis of alphavirus-induced arthritis. BioMed Res. Int. 2013, 2013, 973516. [CrossRef] [PubMed]

54. Cheevers, W.; Cordery-Cotter, R.; McGuire, T.; DeMartini, J. Neutralizing antibody responses and evolution of antigenic variants in monozygotic twin lambs infected with phenotypically distinct ovine lentiviruses. Virology 1999, 258, 382-388. [CrossRef] [PubMed]

55. Herbein, G.; Gras, G.; Khan, K.A.; Abbas, W. Review macrophage signaling in hiv-1 infection. Retrovirology 2010, 7, 34. [CrossRef] [PubMed]

56. Le Douce, V.; Herbein, G.; Rohr, O.; Schwartz, C. Molecular mechanisms of hiv-1 persistence in the monocyte-macrophage lineage. Retrovirology 2010, 7, 32. [CrossRef] [PubMed]

57. Thormar, H. Maedi-visna virus and its relationship to human immunodeficiency virus. AIDS Rev. 2005, 7, 233-245. [PubMed]

58. Oura, C.; Powell, P.; Parkhouse, R. Detection of african swine fever virus in infected pig tissues by immunocytochemistry and in situ hybridisation. J. Virol. Methods 1998, 72, 205-217. [CrossRef]

59. Donofrio, G.; van Santen, V.L. A bovine macrophage cell line supports bovine herpesvirus-4 persistent infection. J. Gen. Virol. 2001, 82, 1181-1185. [CrossRef] [PubMed]

60. Noriega, V.M.; Haye, K.K.; Kraus, T.A.; Kowalsky, S.R.; Ge, Y.; Moran, T.M.; Tortorella, D. Human cytomegalovirus modulates monocyte-mediated innate immune responses during short-term experimental latency in vitro. J. Virol. 2014, 88, 9391-9405. [CrossRef] [PubMed]

61. Münz, C. Epstein Barr Virus Volume 2. One Herpes Virus: Many Diseases; Springer: Berlin, Germany, 2015.

62. Shimakage, M. Significant role of macrophages in human cancers associated with epstein-barr virus (review). Oncol. Rep. 2014, 32, 1763-1771. [CrossRef] [PubMed]

63. Lusso, P. Hhv-6 and the immune system: Mechanisms of immunomodulation and viral escape. J. Clin. Virol. 2006, 37, S4-S10. [CrossRef]

64. Kondo, K.; Kondo, T.; Okuno, T.; Takahashi, M.; Yamanishi, K. Latent human herpesvirus 6 infection of human monocytes/macrophages. J. Gen. Virol. 1991, 72, 1401-1408. [CrossRef] [PubMed]

65. Smith, A.; Santoro, F.; Di Lullo, G.; Dagna, L.; Verani, A.; Lusso, P. Selective suppression of il-12 production by human herpesvirus 6. Blood 2003, 102, 2877-2884. [CrossRef] [PubMed]

66. Rappocciolo, G.; Jenkins, F.J.; Hensler, H.R.; Piazza, P.; Jais, M.; Borowski, L.; Watkins, S.C.; Rinaldo, C.R. Dc-sign is a receptor for human herpesvirus 8 on dendritic cells and macrophages. J. Immunol. 2006, 176, 1741-1749. [CrossRef] [PubMed]

67. Qin, Z.; Freitas, E.; Sullivan, R.; Mohan, S.; Bacelieri, R.; Branch, D.; Romano, M.; Kearney, P.; Oates, J.; Plaisance, K. Upregulation of xct by kshv-encoded micrornas facilitates kshv dissemination and persistence in an environment of oxidative stress. PLoS Pathog. 2010, 6, e1000742. [CrossRef] [PubMed]

68. Henning, J.D.; Bunker, C.H.; Patrick, A.L.; Jenkins, F.J. Human herpesvirus 8 establishes a latent infection in prostates of tobago men resulting in increased macrophage infiltration. Prostate 2016, 76, 735-743. [CrossRef] [PubMed]

69. Mistrikova, J.; Remenova, A.; Lesso, J.; Stancekova, M. Replication and persistence of murine herpesvirus 72 in lymphatic system and peripheral blood mononuclear cells of balb/c mice. Acta Virol. 1994, 38, 151-156. [PubMed]

70. Gowrishankar, K.; Steain, M.; Cunningham, A.L.; Rodriguez, M.; Blumbergs, P.; Slobedman, B.; Abendroth, A. Characterization of the host immune response in human ganglia after herpes zoster. J. Virol. 2010, 84, 8861-8870. [CrossRef] [PubMed]

71. Traina-Dorge, V.; Doyle-Meyers, L.A.; Sanford, R.; Manfredo, J.; Blackmon, A.; Wellish, M.; James, S.; Alvarez, X.; Midkiff, C.; Palmer, B.E.; et al. Simian varicella virus is present in macrophages, dendritic cells, and $t$ cells in lymph nodes of rhesus macaques after experimental reactivation. J. Virol. 2015, 89, 9817-9824. [CrossRef] [PubMed]

72. Grove, J.; Marsh, M. The cell biology of receptor-mediated virus entry. J. Cell Biol. 2011, 195, 1071-1082. [CrossRef] [PubMed]

73. Kerr, M.C.; Teasdale, R.D. Defining macropinocytosis. Traffic 2009, 10, 364-371. [CrossRef] [PubMed] 
74. Murray, P.J.; Wynn, T.A. Protective and pathogenic functions of macrophage subsets. Nat. Rev. Immunol. 2011, 11, 723-737. [CrossRef] [PubMed]

75. Tayyari, F.; Marchant, D.; Moraes, T.J.; Duan, W.; Mastrangelo, P.; Hegele, R.G. Identification of nucleolin as a cellular receptor for human respiratory syncytial virus. Nat. Med. 2011, 17, 1132-1135. [CrossRef] [PubMed]

76. Pawelek, K.A.; Dor, D., Jr.; Salmeron, C.; Handel, A. Within-host models of high and low pathogenic influenza virus infections: The role of macrophages. PLoS ONE 2016, 11, e0150568. [CrossRef] [PubMed]

77. Lai, M.M.; Cavanagh, D. The molecular biology of coronaviruses. Adv. Virus Res. 1997, 48, 1-100. [PubMed]

78. Brahic, M.; Bureau, J.-F.; Michiels, T. The genetics of the persistent infection and demyelinating disease caused by theiler's virus. Annu. Rev. Microbiol. 2005, 59, 279-298. [CrossRef] [PubMed]

79. Lichty, B.D.; Power, A.T.; Stojdl, D.F.; Bell, J.C. Vesicular stomatitis virus: Re-inventing the bullet. Trends Mol. Med. 2004, 10, 210-216. [CrossRef] [PubMed]

80. Otake, Y.; Soundararajan, S.; Sengupta, T.K.; Kio, E.A.; Smith, J.C.; Pineda-Roman, M.; Stuart, R.K.; Spicer, E.K.; Fernandes, D.J. Overexpression of nucleolin in chronic lymphocytic leukemia cells induces stabilization of bcl2 mrna. Blood 2007, 109, 3069-3075. [CrossRef] [PubMed]

81. Hallak, L.K.; Collins, P.L.; Knudson, W.; Peeples, M.E. Iduronic acid-containing glycosaminoglycans on target cells are required for efficient respiratory syncytial virus infection. Virology 2000, 271, 264-275. [CrossRef] [PubMed]

82. Ariza, M.-E.; Glaser, R.; Kaumaya, P.T.; Jones, C.; Williams, M.V. The ebv-encoded dutpase activates nf-kb through the tlr2 and myd88-dependent signaling pathway. J. Immunol. 2009, 182, 851-859. [CrossRef] [PubMed]

83. Liu, J.; Thorp, S.C. Cell surface heparan sulfate and its roles in assisting viral infections. Med. Res. Rev. 2002, 22, 1-25. [CrossRef] [PubMed]

84. Hober, D.; Sane, F.; Jaidane, H.; Riedweg, K.; Goffard, A.; Desailloud, R. Immunology in the clinic review series; focus on type 1 diabetes and viruses: Role of antibodies enhancing the infection with coxsackievirus-b in the pathogenesis of type 1 diabetes. Clin. Exp. Immunol. 2012, 168, 47-51. [CrossRef] [PubMed]

85. Maréchal, V.; Prevost, M.-C.; Petit, C.; Perret, E.; Heard, J.-M.; Schwartz, O. Human immunodeficiency virus type 1 entry into macrophages mediated by macropinocytosis. J. Virol. 2001, 75, 11166-11177. [CrossRef] [PubMed]

86. Trujillo, J.R.; Rogers, R.; Molina, R.M.; Dangond, F.; McLane, M.F.; Essex, M.; Brain, J.D. Noninfectious entry of hiv-1 into peripheral and brain macrophages mediated by the mannose receptor. Proc. Natl. Acad. Sci. USA 2007, 104, 5097-5102. [CrossRef] [PubMed]

87. Kondo, K.; Kondo, T.; Shimada, K.; Amo, K.; Miyagawa, H.; Yamanishi, K. Strong interaction between human herpesvirus 6 and peripheral blood monocytes/macrophages during acute infection. J. Med Virol. 2002, 67, 364-369. [CrossRef] [PubMed]

88. Spear, P.G.; Longnecker, R. Herpesvirus entry: An update. J. Virol. 2003, 77, 10179-10185. [CrossRef] [PubMed]

89. Zerboni, L.; Sen, N.; Oliver, S.L.; Arvin, A.M. Molecular mechanisms of varicella zoster virus pathogenesis. Nat. Rev. Microbiol. 2014, 12, 197-210. [CrossRef] [PubMed]

90. Maginnis, M.S. Virus-receptor interactions: The key to cellular invasion. J. Mol. Boil. 2018, 430, $2590-2611$. [CrossRef] [PubMed]

91. Van Lent, P.L.; Nabbe, K.; Blom, A.B.; Holthuysen, A.E.; Sloetjes, A.; Van De Putte, L.B.; Verbeek, S.; Van Den Berg, W.B. Role of activatory fc $\gamma$ ri and fc $\gamma$ riii and inhibitory fc $\gamma$ rii in inflammation and cartilage destruction during experimental antigen-induced arthritis. Am. J. Pathol. 2001, 159, 2309-2320. [CrossRef]

92. Coyne, C.B.; Shen, L.; Turner, J.R.; Bergelson, J.M. Coxsackievirus entry across epithelial tight junctions requires occludin and the small gtpases rab34 and rab5. Cell Host Microbe 2007, 2, 181-192. [CrossRef] [PubMed]

93. Nguyen, D.G.; Hildreth, J.E. Involvement of macrophage mannose receptor in the binding and transmission of hiv by macrophages. Eur. J. Immunol. 2003, 33, 483-493. [CrossRef] [PubMed]

94. Wang, X.; Huang, D.Y.; Huong, S.-M.; Huang, E.-S. Integrin $\alpha \mathrm{v} \beta 3$ is a coreceptor for human cytomegalovirus. Nat. Med. 2005, 11, 515-521. [CrossRef] [PubMed]

95. Beutler, B. Inferences, questions and possibilities in toll-like receptor signalling. Nature 2004, 430, $257-263$. [CrossRef] [PubMed] 
96. Fujimoto, I.; Pan, J.; Takizawa, T.; Nakanishi, Y. Virus clearance through apoptosis-dependent phagocytosis of influenza a virus-infected cells by macrophages. J. Virol. 2000, 74, 3399-3403. [CrossRef] [PubMed]

97. Dutta, K.; Mishra, M.K.; Nazmi, A.; Kumawat, K.L.; Basu, A. Minocycline differentially modulates macrophage mediated peripheral immune response following japanese encephalitis virus infection. Immunobiology 2010, 215, 884-893. [CrossRef] [PubMed]

98. Chan, G.; Nogalski, M.T.; Bentz, G.L.; Smith, M.S.; Parmater, A.; Yurochko, A.D. Pi3k-dependent upregulation of mcl-1 by human cytomegalovirus is mediated by epidermal growth factor receptor and inhibits apoptosis in short-lived monocytes. J. Immunol. 2010, 184, 3213-3222. [CrossRef] [PubMed]

99. Larrosa, P.N.F.; Croci, D.O.; Riva, D.A.; Bibini, M.; Luzzi, R.; Saracco, M.; Mersich, S.E.; Rabinovich, G.A.; Peralta, L.M. Apoptosis resistance in hiv-1 persistently-infected cells is independent of active viral replication and involves modulation of the apoptotic mitochondrial pathway. Retrovirology 2008, 5, 19. [CrossRef] [PubMed]

100. Avalos, C.R.; Abreu, C.M.; Queen, S.E.; Li, M.; Price, S.; Shirk, E.N.; Engle, E.L.; Forsyth, E.; Bullock, B.T.; Mac Gabhann, F. Brain macrophages in simian immunodeficiency virus-infected, antiretroviral-suppressed macaques: A functional latent reservoir. MBio 2017, 8, e01186-17. [CrossRef] [PubMed]

101. Couturier, J.; Lewis, D.E. Hiv persistence in adipose tissue reservoirs. Curr. HIV/AIDS Rep. 2018, 15, 60-71. [CrossRef] [PubMed]

102. Eriksson, S.; Graf, E.H.; Dahl, V.; Strain, M.C.; Yukl, S.A.; Lysenko, E.S.; Bosch, R.J.; Lai, J.; Chioma, S.; Emad, F. Comparative analysis of measures of viral reservoirs in hiv-1 eradication studies. PLoS Pathog. 2013, 9, e1003174. [CrossRef] [PubMed]

103. Aquaro, S.; Bagnarelli, P.; Guenci, T.; De Luca, A.; Clementi, M.; Balestra, E.; Caliò, R.; Perno, C.F. Long-term survival and virus production in human primary macrophages infected by human immunodeficiency virus. J. Med. Virol. 2002, 68, 479-488. [CrossRef] [PubMed]

104. Gama, L.; Abreu, C.; Shirk, E.N.; Queen, S.E.; Beck, S.E.; Pate, K.A.M.; Bullock, B.T.; Zink, M.C.; Mankowski, J.L.; Clements, J.E. SIV latency in macrophages in the CNS. In Current Topics in Microbiology and Immunology; Springer: Berlin, Germany, 2018.

105. Geleziunas, R.; Xu, W.; Takeda, K.; Ichijo, H.; Greene, W.C. Hiv-1 nef inhibits ask1-dependent death signalling providing a potential mechanism for protecting the infected host cell. Nature 2001, 410, 834-838. [CrossRef] [PubMed]

106. Andrade, V.M.; Stevenson, M. Host and viral factors influencing interplay between the macrophage and hiv-1. J. Neuroimmune Pharmacol. 2018, 1-11. [CrossRef]

107. Ballon, G.; Ometto, L.; Righetti, E.; Cattelan, A.M.; Masiero, S.; Zanchetta, M.; Chieco-Bianchi, L.; De Rossi, A. Human immunodeficiency virus type 1 modulates telomerase activity in peripheral blood lymphocytes. J. Infect. Dis. 2001, 183, 417-424. [CrossRef] [PubMed]

108. Osman, A.; Bhuyan, F.; Hashimoto, M.; Nasser, H.; Maekawa, T.; Suzu, S. M-csf inhibits anti-hiv-1 activity of il-32, but they enhance m2-like phenotypes of macrophages. J. Immunol. 2014, 192, 5083-5089. [CrossRef] [PubMed]

109. Torre, D.; Gennero, L.; Baccino, F.; Speranza, F.; Biondi, G.; Pugliese, A. Impaired macrophage phagocytosis of apoptotic neutrophils in patients with human immunodeficiency virus type 1 infection. Clin. Diagn. Lab. Immunol. 2002, 9, 983-986. [CrossRef] [PubMed]

110. Fadok, V.A.; Bratton, D.L.; Konowal, A.; Freed, P.W.; Westcott, J.Y.; Henson, P.M. Macrophages that have ingested apoptotic cells in vitro inhibit proinflammatory cytokine production through autocrine/paracrine mechanisms involving tgf-beta, pge2, and paf. J. Clin. Investig. 1998, 101, 890-898. [CrossRef] [PubMed]

111. Söderberg-Nauclér, C. Hcmv microinfections in inflammatory diseases and cancer. J. Clin. Virol. 2008, 41, 218-223. [CrossRef] [PubMed]

112. Nogalski, M.T.; Collins-McMillen, D.; Yurochko, A.D. Overview of human cytomegalovirus pathogenesis. Methods Mol. Biol. 2014, 1119, 15-28. [CrossRef] [PubMed]

113. Söderberg-Nauclér, C. Does cytomegalovirus play a causative role in the development of various inflammatory diseases and cancer? J. Intern. Med. 2006, 259, 219-246. [CrossRef] [PubMed]

114. Smith, M.S.; Bentz, G.L.; Smith, P.M.; Bivins, E.R.; Yurochko, A.D. Hcmv activates pi (3) k in monocytes and promotes monocyte motility and transendothelial migration in a pi (3) k-dependent manner. J. Leukoc. Boil. 2004, 76, 65-76. [CrossRef] [PubMed] 
115. Dubuisson, J.; Cosset, F.-L. Virology and cell biology of the hepatitis c virus life cycle-An update. J. Hepatol. 2014, 61, S3-S13. [CrossRef] [PubMed]

116. Revie, D.; Salahuddin, S.Z. Role of macrophages and monocytes in hepatitis c virus infections. World J. Gastroenterol. 2014, 20, 2777-2784. [CrossRef] [PubMed]

117. Brown, A.; Gartner, S.; Kawano, T.; Benoit, N.; Cheng-Mayer, C. Hla-a2 down-regulation on primary human macrophages infected with an m-tropic egfp-tagged hiv-1 reporter virus. J. Leukoc. Boil. 2005, 78, 675-685. [CrossRef] [PubMed]

118. Smith, A.J.; Toledo, C.M.; Wietgrefe, S.W.; Duan, L.; Schacker, T.W.; Reilly, C.S.; Haase, A.T. The immunosuppressive role of il-32 in lymphatic tissue during hiv-1 infection. J. Immunol. 2011, 186, 6576-6584. [CrossRef] [PubMed]

119. Lang, J.; Cheng, Y.; Rolfe, A.; Hammack, C.; Vera, D.; Kyle, K.; Wang, J.; Meissner, T.B.; Ren, Y.; Cowan, C. An hpsc-derived tissue-resident macrophage model reveals differential responses of macrophages to zikv and denv infection. Stem Cell Rep. 2018, 11, 348-362. [CrossRef] [PubMed]

120. Venzke, S.; Keppler, O.T. Role of macrophages in hiv infection and persistence. Expert Rev. Clin. Immunol. 2006, 2, 613-626. [CrossRef] [PubMed]

121. Liao, H.-K.; Gu, Y.; Diaz, A.; Marlett, J.; Takahashi, Y.; Li, M.; Suzuki, K.; Xu, R.; Hishida, T.; Chang, C.-J.; et al. Use of the crispr/cas9 system as an intracellular defense against hiv-1 infection in human cells. Nat. Commun. 2015, 6, 6413. [CrossRef] [PubMed]

122. Kaminski, R.; Chen, Y.; Fischer, T.; Tedaldi, E.; Napoli, A.; Zhang, Y.; Karn, J.; Hu, W.; Khalili, K. Elimination of hiv-1 genomes from human t-lymphoid cells by crispr/cas9 gene editing. Sci. Rep. 2016, 6, 22555. [CrossRef] [PubMed]

123. Lund Laursen, T.; Brøckner Siggard, C.; Kazankov, K.; Damgaard Sandahl, T.; Møller, H.J.; Ong, A.; Douglas, M.W.; George, J.; Tarp, B.; Hagelskjaer Kristensen, L.; et al. Rapid and persistent decline in soluble cd163 with successful direct-acting antiviral therapy and associations with chronic hepatitis c histology. Scand. J. Gastroenterol. 2018, 1-8. [CrossRef] [PubMed]

124. Davis, L.E.; DeBiasi, R.; Goade, D.E.; Haaland, K.Y.; Harrington, J.A.; Harnar, J.B.; Pergam, S.A.; King, M.K.; DeMasters, B.; Tyler, K.L. West nile virus neuroinvasive disease. Ann. Neurol. Off. J. Am. Neurol. Assoc. Child Neurol. Soc. 2006, 60, 286-300. [CrossRef] [PubMed]

125. Seitz, S.; Clarke, P.; Tyler, K.L. Pharmacologic depletion of microglia increases viral load in the brain and enhances mortality in murine models of flavivirus-induced encephalitis. J. Virol. 2018. [CrossRef] [PubMed]

126. Rulli, N.E.; Guglielmotti, A.; Mangano, G.; Rolph, M.S.; Apicella, C.; Zaid, A.; Suhrbier, A.; Mahalingam, S. Amelioration of alphavirus-induced arthritis and myositis in a mouse model by treatment with bindarit, an inhibitor of monocyte chemotactic proteins. Arthr. Rheum. Off. J. Am. Coll. Rheumatol. 2009, 60, 2513-2523. [CrossRef] [PubMed]

127. Fraser, J. Epidemic polyarthritis and ross river virus disease. Clin. Rheum. Dis. 1986, 12, 369-388. [PubMed]

128. Kang, Y.; Cai, Y. Gut microbiota and hypertension: From pathogenesis to new therapeutic strategies. Clin. Res. Hepatol. Gastroenterol. 2018, 42, 110-117. [CrossRef] [PubMed]

129. Bajaj, J.S.; Sterling, R.; Betrapally, N.; Nixon, D.; Fuchs, M.; Daita, K.; Heuman, D.; Sikaroodi, M.; Hylemon, P.; White, M.; et al. Hcv eradication does not impact gut dysbiosis or systemic inflammation in cirrhotic patients. Aliment. Pharmacol. Ther. 2016, 44, 638-643. [CrossRef] [PubMed]

130. Aly, A.M.; Adel, A.; El-Gendy, A.O.; Essam, T.M.; Aziz, R.K. Gut microbiome alterations in patients with stage 4 hepatitis c. Gut Pathog. 2016, 8, 42. [CrossRef] [PubMed]

131. Nowak, P.; Troseid, M.; Avershina, E.; Barqasho, B.; Neogi, U.; Holm, K.; Hov, J.R.; Noyan, K.; Vesterbacka, J.; Svärd, J.; et al. Gut microbiota diversity predicts immune status in hiv-1 infection. Aids 2015, 29, 2409-2418. [CrossRef] [PubMed]

132. Inoue, T.; Nakayama, J.; Moriya, K.; Kawaratani, H.; Momoda, R.; Ito, K.; Iio, E.; Nojiri, S.; Fujiwara, K.; Yoneda, M.; et al. Gut dysbiosis associated with hepatitis c virus infection. Clin. Infect. Dis. 2018, 67, 869-877. [CrossRef] [PubMed]

(C) 2018 by the authors. Licensee MDPI, Basel, Switzerland. This article is an open access article distributed under the terms and conditions of the Creative Commons Attribution (CC BY) license (http:/ / creativecommons.org/licenses/by/4.0/). 